(D) Check for updates

Cite this: Dalton Trans., 2022, 51, 4814

Received 14th December 2021, Accepted 25th February 2022

DOI: $10.1039 / \mathrm{d} 1 \mathrm{dt} 04204 a$

rsc.li/dalton

\section{Oxidation of europium with ammonium perfluorocarboxylates in liquid ammonia: pathways to europium(II) carboxylates and hexanuclear europium(III) fluoridocarboxylate complexes $\uparrow$}

\begin{abstract}
Florian Morsbach, (D) a Steffen Klenner, ${ }^{\mathrm{b}}$ Rainer Pöttgen (D) ${ }^{\mathrm{b}}$ and Walter Frank (D) *a
The novel coordination polymer $\left[\mathrm{Eu}\left(\mathrm{O}_{2} \mathrm{CCF}_{3}\right)_{2}(\mathrm{dmf})_{2}\right]_{\infty}$ (1) (dmf $=\mathrm{N}, \mathrm{N}$-dimethylformamide) containing europium(II) and the two new compounds $\left(\mathrm{NH}_{4}\right)_{2}\left[\mathrm{Eu}_{6} \mathrm{~F}_{8}\left(\mathrm{O}_{2} \mathrm{CCF}_{3}\right)_{12}\left(\mathrm{CF}_{3} \mathrm{COOH}\right)_{6}\right]$ (2) and $\left(\mathrm{NH}_{4}\right)_{2}\left[\mathrm{Eu}_{6} \mathrm{~F}_{8}\left(\mathrm{O}_{2} \mathrm{CC}_{2} \mathrm{~F}_{5}\right)_{12}\left(\mathrm{C}_{2} \mathrm{~F}_{5} \mathrm{COOH}\right)_{6}\right] \cdot 8 \mathrm{C}_{2} \mathrm{~F}_{5} \mathrm{COOH}$ (3), both based on hexanuclear europiate(III) complexes, were synthesized from precursors with $\mathrm{Eu}^{2+}: \mathrm{Eu}^{3+}$ ratio $>1$, obtained by reaction of europium metal with ammonium perfluorocarboxylates in liquid ammonia. In the crystal structure of 1 the europium (II) ions are bridged by carboxylate groups and $\mathrm{N}, \mathrm{N}$-dimethylformamide to form polymeric chains with $\mathrm{Eu}^{2+} \ldots \mathrm{Eu}^{2+}$ distances of $408.39(13)-410.49(13) \mathrm{pm}$. The compound crystallizes in the triclinic space group $P \overline{1}(Z=2)$. To the best of our knowledge, this is the first example of a (solvated) perfluorocarboxylate containing a lanthanoid in a subvalent oxidation state. In the crystal structures of $\mathbf{2}$ and $\mathbf{3}$ the europium(III) ions are bridged by fluoride ions and carboxylate groups to form hexanuclear complex anions with an octahedral arrangement of the cations. The $\mathrm{Eu}^{3+} \ldots \mathrm{Eu}^{3+}$ distances are in the range of 398.27(15)400.93(15) pm in 2 and 395.37(4)-399.78(5) pm in 3, respectively. Both compounds crystallize in the monoclinic space group type $P 2_{1} / n(Z=4)$ and are the first examples of octahedro-hexanuclear europium carboxylates for which fluoride is reported as a bridging ligand. In all compounds the oxidation state of europium was monitored via ${ }^{151} \mathrm{Eu}$ Mössbauer and photoluminescene spectroscopy.
\end{abstract}

\section{Introduction}

Inorganic trifluoroacetates define a well-known class of compounds continuously investigated up to the present time since the first syntheses by Swarts et al. in the year $1922 .^{1}$ More recently, metal trifluoroacetates gained attention as precursors for metal fluorides, the trifluoroacetato ligand being the fluoride source. ${ }^{2}$ Functional fluoridic thin-films or nanomaterials may be accessed this way. ${ }^{3}$ Furthermore, the trifluoroacetate ion proves to be an efficient ligand to stabilize low oxidation states of the d-block metals ${ }^{4}$ as well as subvalent oxidation

\footnotetext{
${ }^{a}$ Institut für Anorganische Chemie und Strukturchemie, Lehrstuhl II: Material- und Strukturforschung, Heinrich-Heine-Universität Düsseldorf, Universitätsstraße 1, D-40225 Düsseldorf, Germany. E-mail: wfrank@hhu.de

${ }^{b}$ Institut für Anorganische und Analytische Chemie, Westfälische WilhelmsUniversität, Corrensstraße 30, D-48149 Münster, Germany

$\dagger$ Electronic supplementary information (ESI) available: Selected structural parameters and empirical bond valences, TGA and DSC curves, IR and NMR spectra, packing diagrams. CCDC 2125846-2125848. For ESI and crystallographic data in CIF or other electronic format see DOI: 10.1039/d1dt04204a
}

states of heavy main group metals as in the case of the dibismuth(II) tetrakis(trifluoroacetate) molecule. ${ }^{5}$ The reason for this behavior can be assumed to be the electron-withdrawing along with the chelating or bridging character of the ligand. We assumed a similar stabilizing effect on the oxidation state + II of the lanthanoids (Ln) by trifluoroacetato and higher perfluorocarboxylato ligands, especially for europium and ytterbium, due to their particular electron configurations among the f-block metals (Eu: [Xe] $4 \mathrm{f}^{7} 6 \mathrm{~s}^{2}$; Yb: [Xe] $4 \mathrm{f}^{14} \quad 6 \mathrm{~s}^{2}$ ). ${ }^{6}$ Although materials containing $\mathrm{Ln}^{2+}$ ions have been known for almost a century ${ }^{7}$ and are still the subject of current research (especially phosphors), ${ }^{8}$ only a very small number of simple europium(II) carboxylates has been reported up to date. ${ }^{9}$ Usually, in the course of crystallization these compounds form chain and network structures to satisfy the lanthanoids' tendency to have high coordination numbers. ${ }^{10}$ The $\mathrm{Ln}^{3+}$ cations tend to give dimeric building units in their solid-state structures, with $O, O^{\prime}$-bridging carboxylato ligands such as $\mathrm{CH}_{3} \mathrm{COO},{ }^{11} \mathrm{CF}_{3} \mathrm{COO}^{12}$ and $\mathrm{C}_{2} \mathrm{~F}_{5} \mathrm{COO} .{ }^{13}$ However, under certain conditions, the formation of polyhedral cages is also observed. Here, in most cases, hydroxide ions cap the polyhedral faces of 
the $[\mathrm{Ln}]_{n}$ cages and ensure maximum cohesion of the $\mathrm{Ln}^{3+}$ centers, while further anions occupy the polyhedral edges and bridge the $\mathrm{Ln}^{3+}$ centers, e.g. polyselenides, ${ }^{14}\left[\mathrm{PdCl}_{4}\right]^{2-},{ }^{15}$ $\beta$-diketonates ${ }^{16}$ and trifluoromethanesulfonate. ${ }^{17}$ To date, only a few lanthanoid complexes can be found in the literature in which perfluorocarboxylate ions serve as bridging ligands. ${ }^{18}$

Herein we report the preparation of europium carboxylates with a high content of $\mathrm{Eu}^{2+}$ by the oxidation of europium with ammonium perfluorocarboxylates in liquid ammonia as solvent. Due to the oxidation sensitivity ${ }^{19}$ of $\mathrm{Ln}^{2+}$ and the Lewis acidity ${ }^{20}$ of $\mathrm{Ln}^{3+}$ ions, we assumed interesting subsequent chemistry for this class of substances, with special regard to perfluorocarboxylate ions as a potential source of fluoride ions. Based on the products of oxidation in liquid ammonia we succeeded in the synthesis and characterization of a solvated europium(II) trifluoroacetate 1, and in the further oxidation by perfluorocarboxylic acids to hexanuclear europium complexes, $\left(\mathrm{NH}_{4}\right)_{2}\left[\mathrm{Eu}_{6} \mathrm{~F}_{8}\left(\mathrm{O}_{2} \mathrm{CR}\right)_{12}(\mathrm{RCOOH})_{6}\right]$, with $\mathrm{R}=$ $\mathrm{CF}_{3}$ (2) and $\mathrm{R}=\mathrm{C}_{2} \mathrm{~F}_{5}$ (3). To the best of our knowledge, compounds 1,2 and 3 are the first $\mathrm{Eu}^{\mathrm{II}}$ perfluorocarboxylate and the first $\mathrm{Eu}^{\mathrm{III}}$ derivatives of hexanuclear $\mathrm{Ln}^{\mathrm{III}}$ fluoridocarboxylates, ${ }^{21}$ respectively.

\section{Results and discussion}

Oxidation of europium with ammonium perfluorocarboxylates in liquid ammonia

The stabilizing effect of liquid ammonia as a reaction medium on $\mathrm{Eu}^{2+}$ ions has been known for decades ${ }^{22}$ and has been used, for example, in the synthesis of $\mathrm{Eu}\left(\mathrm{C}_{5} \mathrm{H}_{5}\right)_{2},{ }^{23} \mathrm{Eu}\left(\mathrm{PH}_{2}\right)_{2},{ }^{24}$ $\mathrm{Eu}\left(\mathrm{NH}_{2}\right)_{2},{ }^{25}$ and of unsolvated europium(II) halides. ${ }^{26}$

It was reasonable to assume that liquid ammonia might also be a suitable solvent for the synthesis of unsolvated europium(II) trifluoroacetate, which is not yet known. In fact, the addition of ammonium trifluoroacetate to the blue solutions of europium in liquid ammonia results in the precipitation of a yellow solid. By evaporation of the ammonia an air-sensitive powder can be obtained, that did not diffract in PXRD experiments. In addition to some content of $\mathrm{NH}_{4} \mathrm{~F}$ (detected via ion chromatography, elemental analysis, and IR spectroscopy), a ratio of $77 \% \mathrm{Eu}^{2+}$ to $23 \% \mathrm{Eu}^{3+}$ was detected via ${ }^{151} \mathrm{Eu}$
Mössbauer spectroscopy. Under similar reaction conditions, also a yellow powder with a ratio of $50 \% \mathrm{Eu}^{2+}$ to $50 \% \mathrm{Eu}^{3+}$ was obtained from ammonium pentafluoropropionate, generated in situ by dissolving anhydrous pentafluoropropionic acid in liquid ammonia. It can be concluded from the analytical results that the substances contain high amounts of $\mathrm{Eu}^{\mathrm{II}}$ compounds, including europium(II) trifluoroacetate and europium (II) pentafluoropropionate, and that the decomposition of the perfluorocarboxylate ions, with simultaneous oxidation of the europium, plays an important role as a side reaction.

\section{catena-Poly[europium(II)bis( $\mu_{2}-N, N$-dimethylformamide $)$ bis $\left(\mu_{2^{-}}\right.$} trifluoroacetato $)],\left[\mathrm{Eu}\left(\mathrm{O}_{2} \mathrm{CCF}_{3}\right)_{2}(\mathrm{dmf})_{2}\right]_{\infty}(1)$

Synthesis and characterization. In the task of purification of the substances described above, the solvent selection is limited to aprotic solvents due to the inherent protolysis sensitivity. In trifluoroacetic anhydride, the $\mathrm{Eu}\left(\mathrm{O}_{2} \mathrm{CCF}_{3}\right)_{2}$-containing substance proved to be insoluble. With $N, N$-dimethylformamide (DMF) a yellow suspension results that can be separated to give a white solid and a clear, yellow solution. After this solution had been concentrated to half of its initial volume, it was stored in a closed ampoule at $8{ }^{\circ} \mathrm{C}$. After 1-2 weeks very fine yellow crystal needles of 1 could be harvested. A single crystal of $\mathbf{1}$ suitable for crystal structure analysis could be selected directly from the solution. Subsequently, the mother liquor was removed, and the remaining yellow crystals dried in vacuo. A ratio of $88 \% \mathrm{Eu}^{2+}$ to $12 \% \mathrm{Eu}^{3+}$ was detected via ${ }^{151} \mathrm{Eu}$ Mössbauer spectroscopy. However, the signal intensity in a Mössbauer spectrum depends on the strength of the bonding of the europium atom in the crystal structure, which could not be considered here. Thus, the atomic ratio of $\mathrm{Eu}^{2+}$ to $\mathrm{Eu}^{3+}$ can only be approximated from the area ratio. The small amount of oxidation product is probably due to the isolation of the extremely oxidation-sensitive substance from the mother liquor and the preparation for the ${ }^{151} \mathrm{Eu}$ Mössbauer spectroscopic measurements. The results of the ${ }^{151} \mathrm{Eu}$ Mössbauer spectroscopic studies of $\mathbf{1}$ and of the two precursors are summarized in Table 1 along with the results for 2 and 3 that will be discussed later. The spectra are shown in Fig. 1. ATR-IR spectroscopy of freshly harvested crystals of $\mathbf{1}$ showed the typical bands of trifluoroacetates and of DMF. The compound turned out to be a labile solvate that loses some

Table 1 Fitting parameters of the ${ }^{151}$ Eu Mössbauer spectroscopic measurements of 1, 2 and 3, and their corresponding precursors

\begin{tabular}{|c|c|c|c|c|c|}
\hline Compound & Temperature & $\delta\left[\mathrm{mm} \mathrm{s}^{-1}\right]$ & $\Delta E_{\mathrm{Q}}\left[\mathrm{mm} \mathrm{s}^{-1}\right]$ & $\Gamma\left[\mathrm{mm} \mathrm{s}^{-1}\right]$ & Area $[\%]$ \\
\hline \multirow[t]{2}{*}{ Precursor for 1 and 2} & \multirow[t]{2}{*}{$6 \mathrm{~K}$} & $-13.11(2)$ & $4.4(2)$ & $4.10(8)$ & $77(1)$ \\
\hline & & $0.35(2)$ & $2.9(2)$ & $2.32(11)$ & $23(1)$ \\
\hline \multirow[t]{2}{*}{ Precursor for 3} & \multirow[t]{2}{*}{$6 \mathrm{~K}$} & $-13.11(2)$ & $4.3(2)$ & $3.78(13)$ & $50(1)$ \\
\hline & & $0.29(1)$ & $2.74(11)$ & $2.31(6)$ & $50(1)$ \\
\hline \multirow[t]{2}{*}{ Compound 1} & \multirow[t]{2}{*}{$78 \mathrm{~K}$} & $-13.33(1)$ & $3.68(7)$ & $3.85(3)$ & $88(1)$ \\
\hline & & $0.31(2)$ & $3.2(2)$ & $2.30(10)$ & $12(1)$ \\
\hline Compound 2 & $78 \mathrm{~K}$ & $0.18(1)$ & $2.62(7)$ & $2.3^{*}$ & 100 \\
\hline Compound 3 & $78 \mathrm{~K}$ & $0.31(2)$ & $2.09(13)$ & $2.3^{*}$ & 100 \\
\hline
\end{tabular}

$\delta=$ isomer shift, $\Delta E_{\mathrm{Q}}=$ quadrupole splitting, $\Gamma$ = experimental line width. Parameters marked with an asterisk were kept fixed during the fitting procedure. 


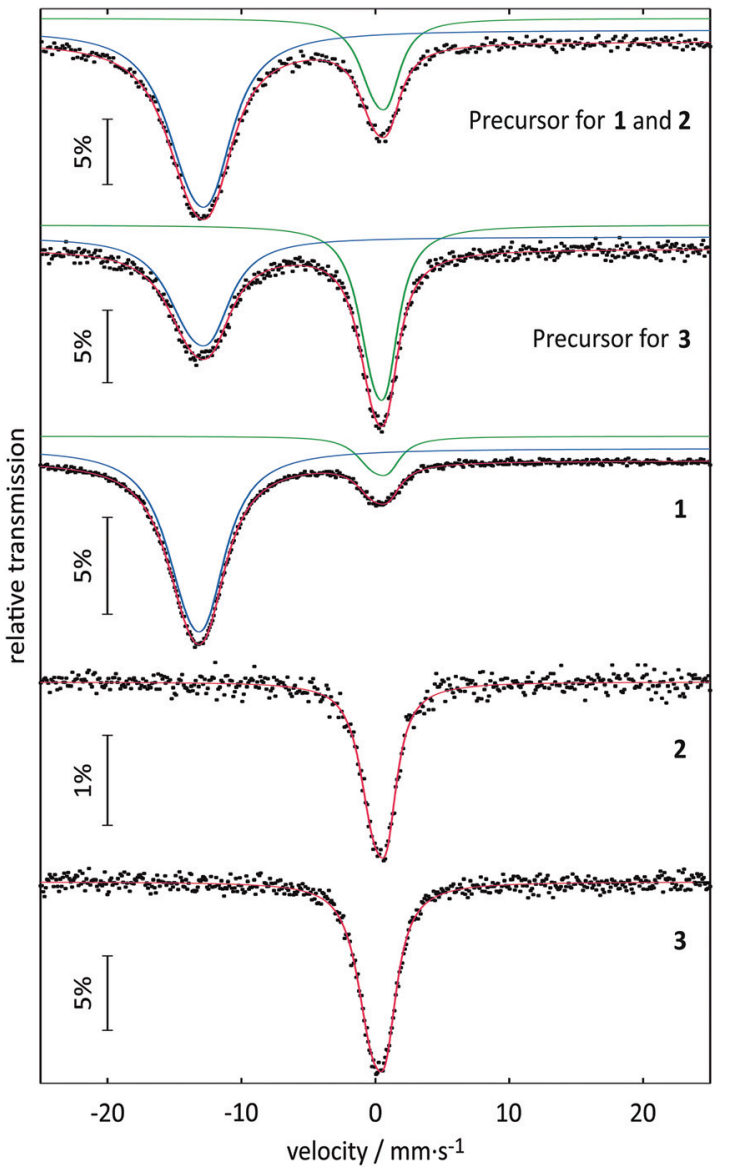

Fig. $1{ }^{151}$ Eu Mössbauer spectra of 1, 2 and 3 (at $78 \mathrm{~K}$ ), and their corresponding precursors (at $6 \mathrm{~K}$ ). Signals with isomer shifts around $0 \mathrm{~mm} \mathrm{~s}^{-1}$ correspond to $\mathrm{Eu}^{3+}$ and signals around $-13 \mathrm{~mm} \mathrm{~s}^{-1}$ correspond to $\mathrm{Eu}^{2+}$. The experimental data are represented by the dotted lines and the fitted data are represented by the colored lines.

DMF even at room temperature in the absence of mother liquor. Not unexpectedly, CHN analysis in several attempts always indicated partial loss of DMF for the 'dried' substance. If 'dried' in vacuum $\left(5 \times 10^{-3} \mathrm{hPa}, 1 \mathrm{~h}\right)$ about one equivalent of DMF is lost and the remaining yellow powder can be stored for at least three months in the absence of moisture. Samples were investigated via TGA/DSC-thermal analysis and PXRD. However, the latter method failed due to the lability of the substance that decomposed in the X-ray beam. The thermal analysis of the product indicated a mass loss of about one equivalent DMF ( $13 \%$; calc. $13.95 \%$ for one eq. DMF) in connection with a broad endothermic event between room temperature and $180^{\circ} \mathrm{C}$ (see Fig. S1 and S2, ESI $\dagger$ ). A further endothermic feature indicated melting of the substance $\left(T_{\text {onset }}=\right.$ $221{ }^{\circ} \mathrm{C}$ ), directly followed up by strong exothermic features $\left(T_{\text {onset }}=255{ }^{\circ} \mathrm{C}\right.$ ) that are related to a mass loss compatible to the complete decomposition of the substance in a narrow range of temperature. The remaining amorphous substance $(\sim 45 \%)$ is assumed to be $\mathrm{EuF}_{3}$ mainly (calc. $46.32 \%$, based on 1). In the course of a single crystal structure analysis 1 was finally proved to be the bis(DMF) adduct of $\mathrm{Eu}\left(\mathrm{O}_{2} \mathrm{CCF}_{3}\right)_{2}$.

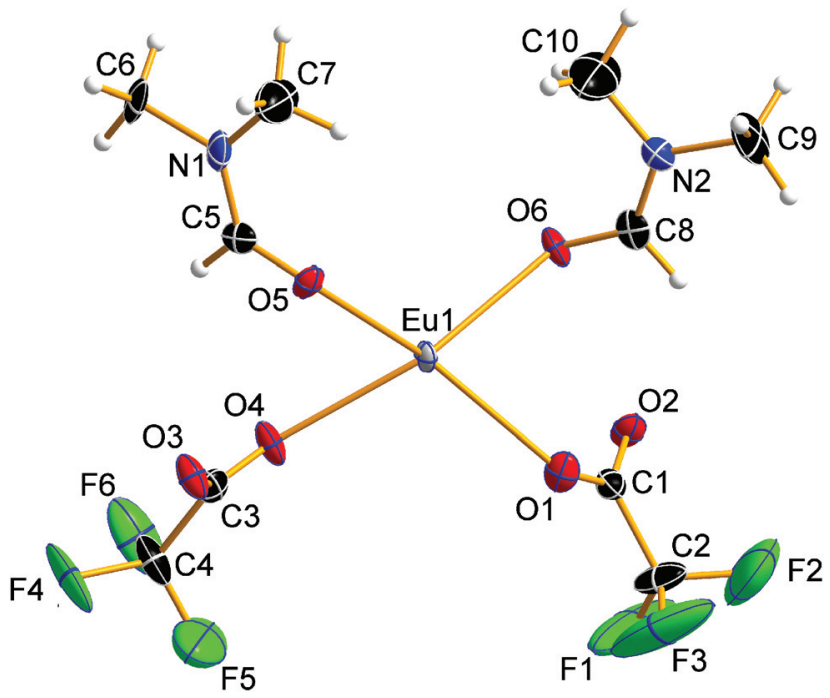

Fig. 2 Asymmetric unit of 1. Displacement ellipsoids are drawn at the $50 \%$ probability level, hydrogen atoms are drawn with an arbitrary radius. The trifluoromethyl group at carbon atom $\mathrm{C} 3$ is disordered. For the sake of clarity, only one of the partial occupation sites is shown.

Crystal structure analysis. Compound 1 crystallizes in the triclinic space group $P \overline{1}(Z=2)$. The asymmetric unit of the crystal structure is shown in Fig. 2 and contains one $\mathrm{Eu}^{2+}$ ion, two trifluoroacetate ions, and two DMF molecules (all in general position). The central $\mathrm{Eu}^{2+}$ ion is coordinated by a total of eight oxygen atoms, four in the asymmetric unit and four symmetry-equivalent ones. The bond valences $s_{\mathrm{i}}$ and the valence sum $S$ of the europium atoms were calculated from the Eu1-Oi bond lengths $d_{\mathrm{i}}$ according to the empirical bond valence method ${ }^{27}$ (see Table S1, ESI $\dagger$ ). The valence sum of 1.92 shows good agreement with the expected value of 2.00. This ensures that the structure determination on a solvated $\mathrm{Eu}^{\mathrm{II}}$ trifluoroacetate has been achieved.

The Eu ${ }^{\mathrm{II}}-\mathrm{O}$ bond lengths in 1 are 2.542(6)-2.623(6) A, which is within the expected range for europium(II) carboxylates, of 2.39-2.87 $\AA$ (mean 2.63 $⿱$ )..$^{9 b-f}$ The $\mathrm{Eu}^{2+}$ ions are connected to polymeric strands by two bridging trifluoroacetato ligands and two bridging molecules of DMF. The orientation of these bridging ligands is shown in Fig. 3. Note the alternating position of the ligands along the chain growth direction, to avoid the collision of adjacent trifluoroacetate groups. A coordination polymer with Eu...Eu distances of 4.0838(13)-4.1049(13) A and inversion centers between two $\mathrm{Eu}^{2+}$ ions is formed in which the $\mathrm{Eu}^{2+}$ ions are in square-antiprismatic coordination. As shown in Fig. 3 the individual coordination polyhedra are edge-linked to each other. The square antiprismatic coordination polyhedron is consistent with the tendency of the lanthanoid ions to prefer high coordination numbers in solution and in the solid state. ${ }^{10}$ Lanthanoid ions prefer (capped) trigonal-prismatic coordination polyhedra with monodentate ligands, e.g., in $\left[\mathrm{Ln}\left(\mathrm{H}_{2} \mathrm{O}\right)_{n}\right]^{3+}$ ions, and square-antiprismatic coordination polyhedra with bridging ligands. ${ }^{10 a}$ The linkage pattern of the $\mathrm{Eu}^{2+}$ ions in $\mathbf{1}$ is closely related to that of 


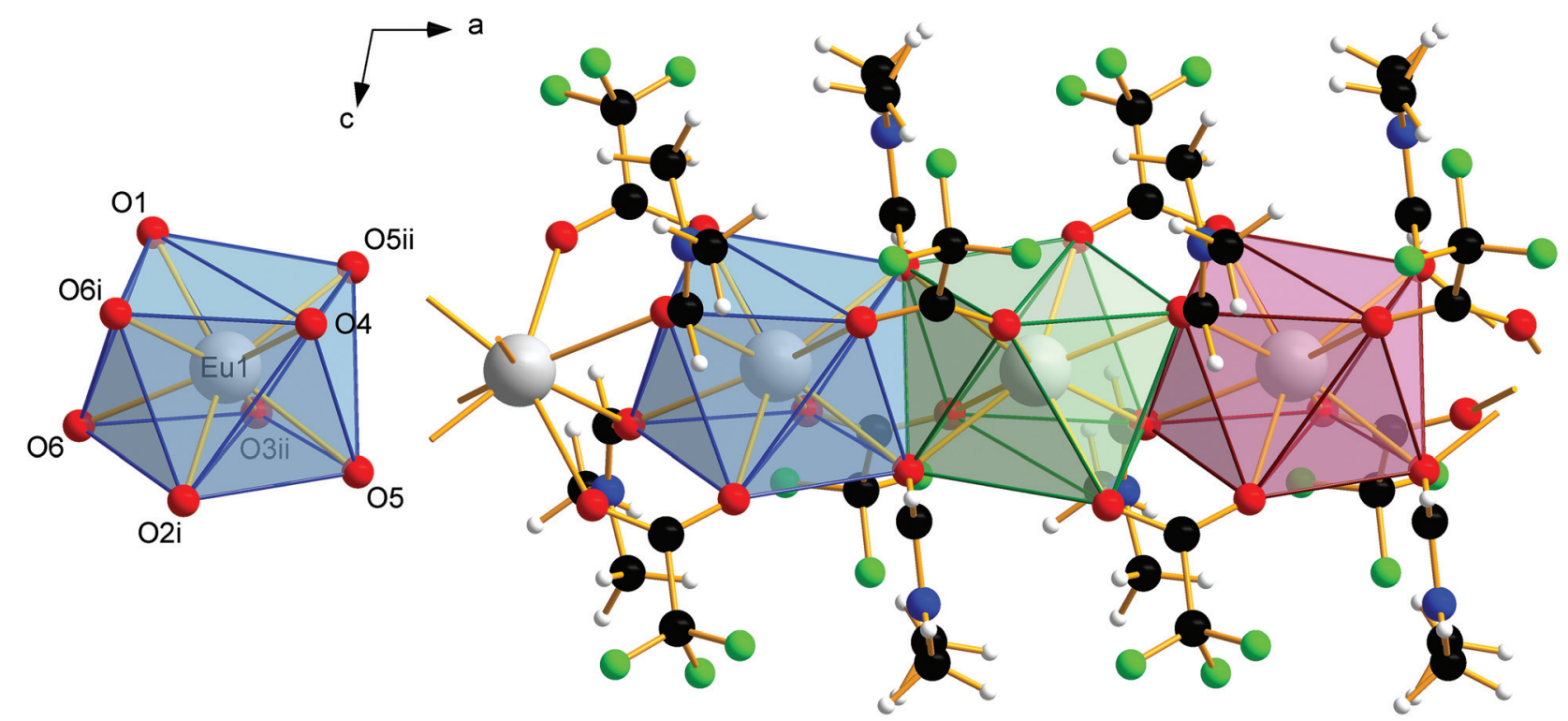

Fig. 3 Coordination polyhedron of Eu1 in 1 (left). Symmetry codes: (i) $1-x, 1-y, 1-z$; (ii) $-x, 1-y, 1-z$. Note the eightfold coordination of the $\mathrm{Eu}^{2+}$ ions by oxygen atoms in square antiprismatic coordination polyhedra. Section of the coordination polymer 1, with four repeating units (right). Direction of view against the crystallographic $b$-axis. The $\mathrm{Eu}^{2+}$ ions are linked by two bridging trifluoroacetato ligands and two bridging molecules of $\mathrm{N}, \mathrm{N}$-dimethylformamide. The individual coordination polyhedra are edge-linked to each other. Color code: C (black), H (white), N (blue), O (red), $\mathrm{F}$ (green), Eu (gray).

$\left[\mathrm{Eu}_{2}\left[\mathrm{C}_{6} \mathrm{H}_{3}\left(\mathrm{NH}_{2}\right)\left(\mathrm{SO}_{3}\right)_{2}\right]_{2}(\mathrm{dmf})_{4}\right]_{\infty}$ mentioned in a personal communication to $\mathrm{CSD}^{28}$ The $\mathrm{Eu} \cdots \mathrm{Eu}$ distances are in the same range of 4.0964(5)-4.1251(5) A. Since these distances heavily depend on the nature of the bridging ligands and their coordination mode, comparisons to other europium(II) carboxylates are less instructive (4.24-4.30 ̊). ${ }^{9 b-f}$ Usually, Ln $\cdots$ Ln distances in exclusively perfluorocarboxylate bridged complexes are about $4.5 \AA^{13}{ }^{13}$ The involvement of DMF or other monodentate bridging ligands seems to give shorter $\mathrm{Eu} \cdots \mathrm{Eu}$ distances. In contrast to the two catena-compounds mentioned above with linear arrangements of $\mathrm{Eu}^{2+}$, the $\mathrm{Eu}^{2+}$ ions in $\left[\mathrm{Eu}(\mathrm{OAc})_{2}(\mathrm{HAc})_{2}\left(\mathrm{H}_{2} \mathrm{O}\right)_{2}\right]_{\infty}$ are arranged in a zig-zag pattern. ${ }^{9 c}$ The $\mathrm{O}-\mathrm{C}-\mathrm{O}^{\prime}$ bond angles of the trifluoroacetate ions in $\mathbf{1}$ are 130.8(10)-131.7(10) ${ }^{\circ}$, which is within the expected range for bidentate carboxylates. ${ }^{11 g, 13,18 a}$

van der Waals interactions between methyl and trifluoromethyl groups of adjacent strands in $\mathbf{1}$ cause the solid-state association. The absence of stronger interactions, such as hydrogen bonds, perpendicular to the chain growth direction explains the crystal habit and the mechanical lability of these hair-fine needles.

\section{Hexanuclear europium(III) fluoridocarboxylates by slow oxidation of europium(II) perfluorocarboxylates}

Synthesis and characterization. In aqueous solutions $\mathrm{Eu}^{2+}$ ions are thermodynamically unstable due to the negative standard potential of $-0.38 \mathrm{~V}^{29}$ However, in the absence of oxygen solutions containing $\mathrm{Eu}^{2+}$ ions are practically stable due to the kinetic barrier of the hydrolysis. ${ }^{30}$ We observed a similar stability of $\mathrm{Eu}^{2+}$ ions in solutions of europium(II) perfluorocarboxy- lates in anhydrous perfluorocarboxylic acids. In a closed tube, the resulting yellow solutions can be stored at least two years without any decolorization, that easily would allow to recognize an oxidation process. However, in PTFE ring sealed ampoules at $8{ }^{\circ} \mathrm{C}$ colorless crystals of 2 and 3 grew within 2-3 weeks. Coulometric Karl Fischer titrations of the mother liquors from the crystallizations of $\mathbf{2}$ and $\mathbf{3}$ gave water contents of $2 \%$ and $1 \%$, respectively. The crystals of 2 and 3 were identified via single crystal structure analysis as complexes of the type $\left(\mathrm{NH}_{4}\right)_{2}\left[\mathrm{Eu}_{6} \mathrm{~F}_{8}\left(\mathrm{O}_{2} \mathrm{CR}\right)_{12}(\mathrm{RCOOH})_{6}\right], \mathrm{R}=\mathrm{CF}_{3}(2)$ and $\mathrm{R}=\mathrm{C}_{2} \mathrm{~F}_{5}$ (3), respectively. Therefore, it is likely that atmospheric oxygen and moisture penetrating the PTFE seals are responsible for a slow oxidation of the yellow solutions. However, it is known that, for example, $\mathrm{Eu}(\mathrm{OH})_{2} \cdot \mathrm{H}_{2} \mathrm{O}$ is subject to a slow oxidative hydrolysis process in the absence of oxygen. ${ }^{31}$ In further experiments a much faster decolorization of the yellow solutions can be achieved even in the absence of oxygen by using equimolar mixtures of perfluorocarboxylic acid and water. In preliminary experiments crystals grown from such solutions are not $\mathbf{2}$ or $\mathbf{3}$ but hydrated substances.

Crystals of $\mathbf{2}$ are stable at room temperature in the absence of moisture. Crystals of 3 readily decompose in the absence of mother liquor releasing acid to give a white solid. After removing the released acid in vacuum, this solid, like 2 , is stable at room temperature. Assuming the general formula given above, for both, 2 and the white solid derived from 3, TGA/DSCthermal analysis indicated a stepwise endothermic release of about six equivalents of acid in the temperature range of room temperature to $185{ }^{\circ} \mathrm{C}(\sim 20 \%$, calc. $21.78 \%$ for 6 eq. acid $)$ and room temperature to $205{ }^{\circ} \mathrm{C}(\sim 22 \%$, calc. $24.36 \%$ for 6 eq. 
acid), respectively (see Fig. S3-S6, ESI $\dagger$ ). Without previous melting the step of final decomposition in the TGA curve is observed at about $20{ }^{\circ} \mathrm{C}$ higher temperature in the case of 3 $\left(T_{\text {onset }}=\sim 280{ }^{\circ} \mathrm{C}\right)$ as compared to $2\left(T_{\text {onset }}=\sim 255{ }^{\circ} \mathrm{C}\right)$. The remaining amorphous substances $(\sim 36 \%$ and $\sim 34 \%)$ are assumed to be $\mathrm{EuF}_{3}$ mainly (calc. $39.92 \%$, based on 2 and $31.03 \%$, based on $\left.3-8 \mathrm{C}_{2} \mathrm{~F}_{5} \mathrm{COOH}\right)$.

Although the isomer shifts in the ${ }^{151} \mathrm{Eu}$ Mössbauer spectra of 2 and 3 both are compatible with trivalent europium, the isomer shifts are different (also with respect to their standard deviations), indicating a ligand-driven change in the electron density at the europium nuclei (see Table 1). Such isomer shift changes are usually a consequence of electronegativity changes, as exemplarily listed for the series: (i) $\operatorname{EuF}_{3}(-0.59) \rightarrow$ $\mathrm{EuCl}_{3}(-0.42) \rightarrow \mathrm{EuBr}_{3}(-0.06)$; (ii) EuOF $(-0.72) \rightarrow$ EuOCl $(-0.43) \rightarrow \operatorname{EuOBr}(-0.29) \rightarrow$ EuOI $(+0.02)$ or (iii) $\mathrm{EuPO}_{4}(0.16)$ $\rightarrow \mathrm{EuAsO}_{4}(0.49) \rightarrow$ EuSbO $_{4}(0.86)$ (all values in $\mathrm{mm} \mathrm{s}^{-1}$ ). ${ }^{32}$ Thus, within these series the highest electron density occurs at the europium nuclei of $\mathrm{EuBr}_{3}$, EuOI and $\mathrm{EuSbO}_{4}$. This trend also holds for 2 and 3 described herein. 3, with an isomer shift of $0.31(2) \mathrm{mm} \mathrm{s}^{-1}$ and the less electron withdrawing moiety $-\mathrm{CF}_{2}-\mathrm{CF}_{3}$ shows higher electron density at the europium nuclei as compared to $0.18(1) \mathrm{mm} \mathrm{s}^{-1}$ for 2 with $-\mathrm{CF}_{2}-\mathrm{F}$. Thus, the ${ }^{151} \mathrm{Eu}$ spectra nicely reflect the small electronic differences induced by the substituent in the ligand.

On the question: fluoride or hydroxide?. There are reasons to question the suggested composition of the complexes, since fluoride and hydroxide are hardly different from each other in XRD experiments due to similar electron numbers of $\mathrm{F}$ and $\mathrm{O}$. $\mu_{3}$-Capping hydroxido ligands are well known in complexes of this type that are typical hydrolysis products. $^{33}$ Therefore, careful study is necessary to exclude this ion for occupation of the octahedral faces. Striking evidence for $\mu_{3}$-capping fluoride ligands: (i) the physical meaningful refinement of the crystal structure. The alternative structure refinement with atomic form factors for $\mathrm{O}$ instead of $\mathrm{F}$ resulted in physically absurd anisotropic displacement parameters; (ii) the calculation of the empirical valence sums gives a significantly better agreement assuming Eu-F bonds (mean $S=3.14$ in 2 and 3.22 in 3) than for the approach as Eu-O bonds (mean $S=3.60$ in 2 and 3.68 in 3) and confirms that these are complexes of the type $\left[\mathrm{Eu}_{6} \mathrm{~F}_{8}\right]$ and not $\left[\mathrm{Eu}_{6}(\mathrm{OH})_{8}\right]$; (iii) by hydrolysis the fluoride ions bound to europium were released and could be detected via ${ }^{19}$ NMR spectroscopy. That these fluoride ions do not originate from a hydrolysis of the perfluorocarboxylate ions is ensured, since $\mathrm{Eu}\left(\mathrm{O}_{2} \mathrm{CCF}_{3}\right)_{3}$ did not show this behavior (see Fig. S17, ESI $\dagger$ ); (iv) there is a very recent example of a complex of the type $\left[\mathrm{Tb}_{6} \mathrm{~F}_{8}\right]$ in literature, with pivalic acid as a carboxylate ligand. ${ }^{21}$

\section{Crystal structure of bis(ammonium) $\left[\right.$ dodecakis( $\mu_{2}$-trifluoro- acetato)-hexakis(trifluoroacetic acid)octa- $\mu_{3}$-fluorido-octahedro- hexaeuropiate(III)], $\left(\mathrm{NH}_{4}\right)_{2}\left[\mathrm{Eu}_{6} \mathrm{~F}_{8}\left(\mathrm{O}_{2} \mathrm{CCF}_{3}\right)_{12}\left(\mathrm{CF}_{3} \mathrm{COOH}\right)_{6}\right]$ (2)}

Compound 2 crystallizes in the monoclinic space group $P 2_{1} / n$ $(Z=4)$. The colorless crystals of 2 are notoriously twinned. For the course of X-ray crystal structure determination, twinning

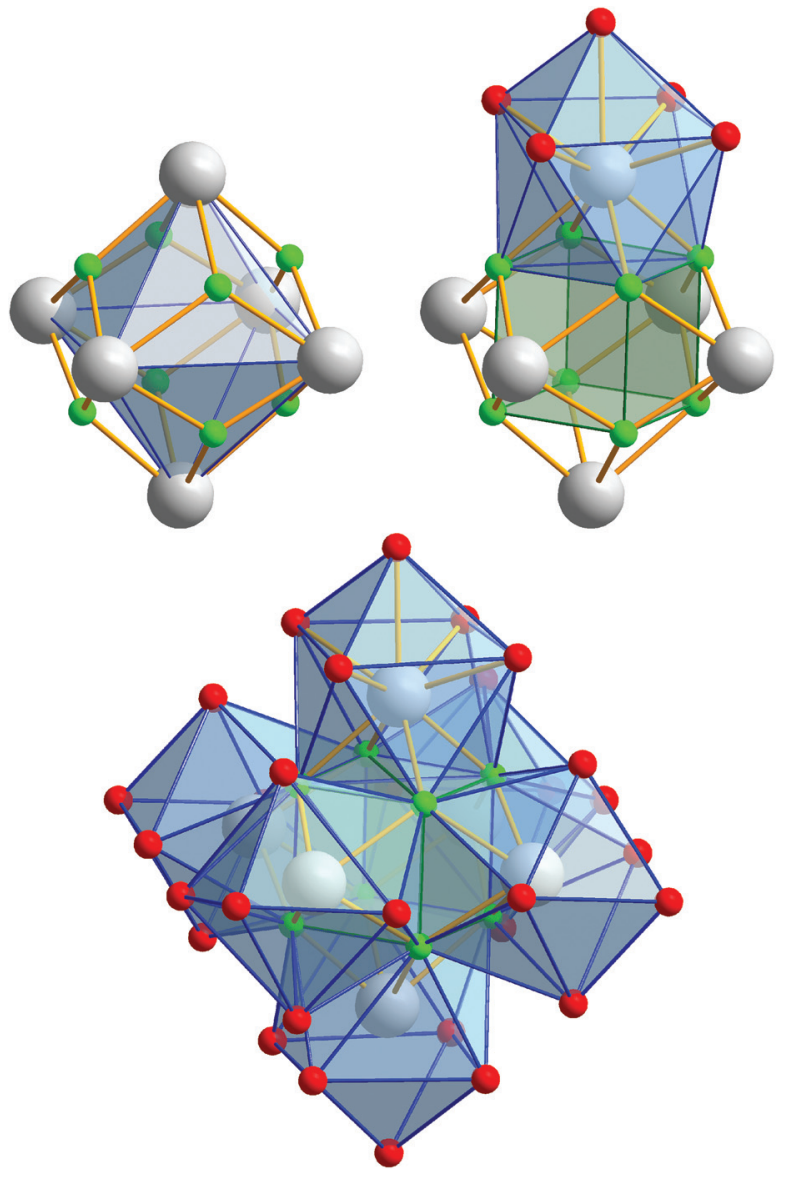

Fig. 4 Different polyhedra of the central unit of 2. The $\mathrm{Eu}^{3+}$ ions span an octahedron whose eight octahedral faces are capped by fluoride ions. These fluoride ions form a $\left[\mathrm{F}_{8}\right]$ cube interpenetrating the $\left[\mathrm{Eu}_{6}\right]$ octahedron. Each of the six cube faces forms the bottom face for a single-capped square antiprismatic coordination polyhedron in which the $\mathrm{Eu}^{3+}$ ions are ninefold coordinated; note the almost identical construction of the central unit of 3 , discussed later. Color code: $O$ (red), $F$ (green), Eu (gray).

had to be considered. Details are given in the Experimental section. The asymmetric unit $\$$ of the crystal structure contains six $\mathrm{Eu}^{3+}$ ions, two $\mathrm{NH}_{4}{ }^{+}$ions (including $\mathrm{N} 1, \mathrm{~N} 2$ ), eight fluoride ions (F1-F8), twelve trifluoroacetate ions and six molecules of trifluoroacetic acid (all in general position). The general structural feature is an octahedral framework of six $\mathrm{Eu}^{3+}$ ions. The eight octahedral faces are capped by fluoride ions to form a $\left[\mathrm{Eu}_{6} \mathrm{~F}_{8}\right]$ unit. Each of the twelve edges and six vertices of the $\left[\mathrm{Eu}_{6}\right]$ octahedron, is coordinated by oxygen atoms of peripheral ligands as shown in Fig. 4. The Eu-F and $\mathrm{Eu}-\mathrm{O}$ bond lengths along with the corresponding empirical bond valences $s_{\mathrm{i}}$ are given in Table S2 (ESI†). The valence sums of the europium

$\$$ Because of the large number of atoms in the asymmetric units of 2 and 3 , these are not shown in a single figure, contrary to the usual conventions, for reasons of clarity; instead, the designation of the atoms and the illustration of their anisotropic displacement parameters is divided among several figures in the discussion of these structures. 
(a)
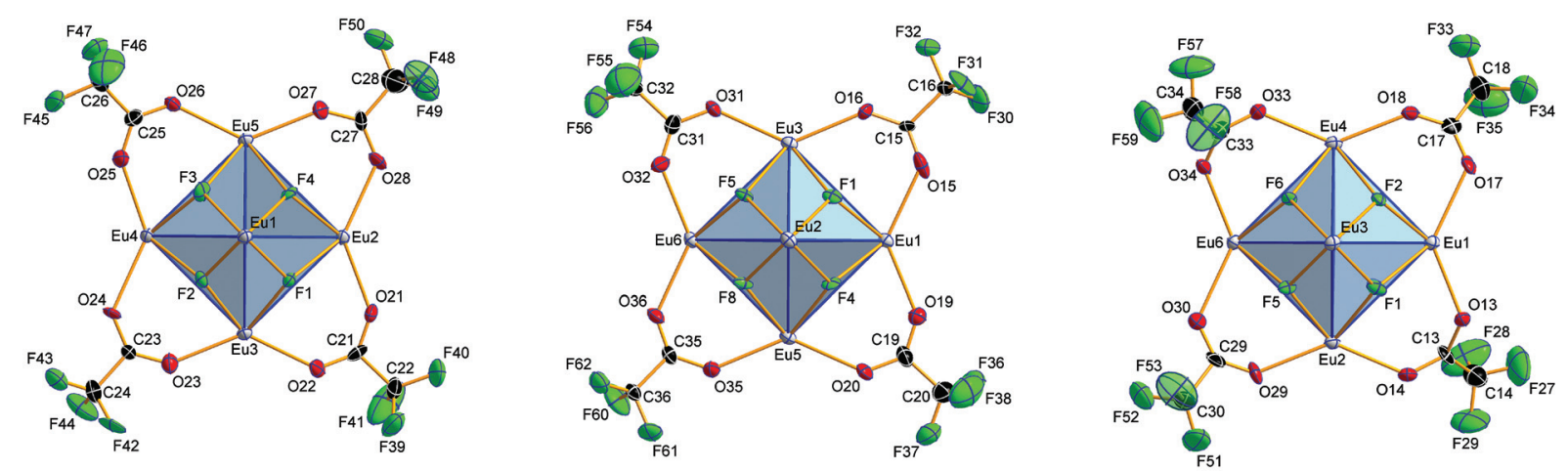

(b)
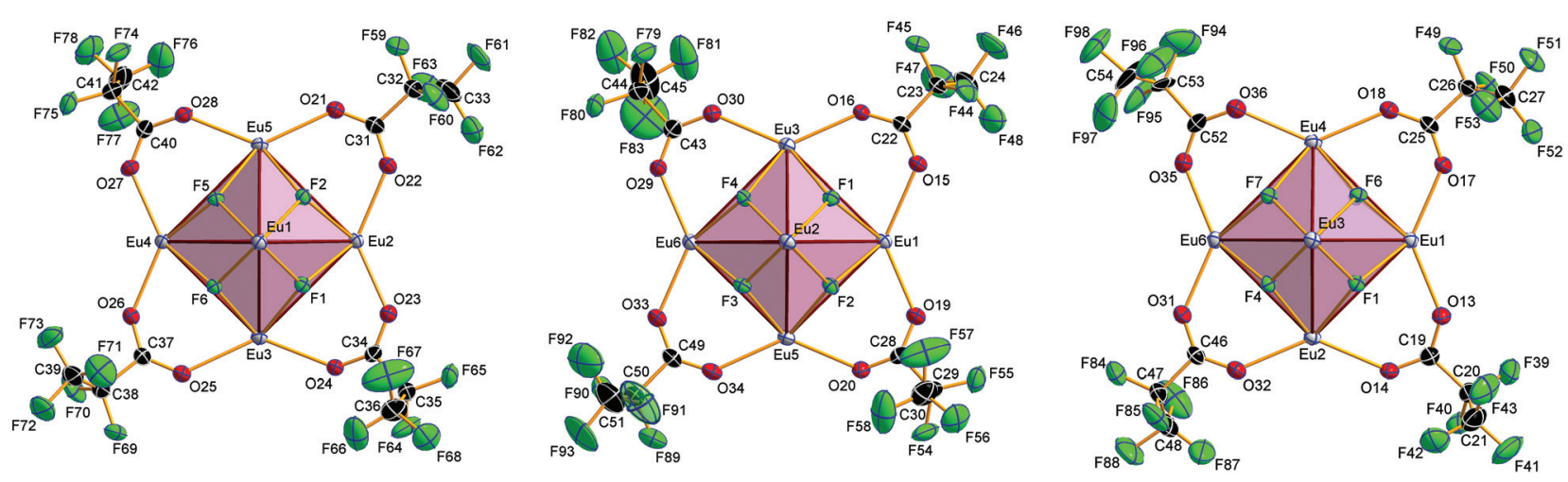

Fig. 5 Coordination of the three 'equatorial planes' in the central $\left[\mathrm{Eu}_{6} \mathrm{~F}_{8}\right]$ unit in 2 (part a) and 3 (part b). Direction of view along Eu1 $\ldots$ Eu6 (left),

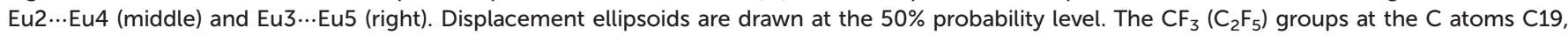
C23, C27 and C31 (C31 and C52) are disordered. For the sake of clarity, only one of the partial occupation sites is shown. The trifluoroacetato (pentafluoropropionato) ligands at the edges of the 'meridional planes' and the trifluoroacetic (pentafluoropropionic) acid molecules at the octahedral vertices are omitted.

atoms have been discussed above and indicate the presence of eight $\mu_{3}$-fluorido ligands that form a $\left[\mathrm{F}_{8}\right]$ cube interpenetrating the $\left[\mathrm{Eu}_{6}\right]$ octahedron in the central $\left[\mathrm{Eu}_{6} \mathrm{~F}_{8}\right]$ unit. Each of the cube's six faces is the basis for one of the six square antiprismatic coordination polyhedra of Eu1-Eu6. The top face of each of these coordination polyhedra is capped by another $\mathrm{O}$ atom, giving ninefold coordinated $\mathrm{Eu}^{3+}$ ions. The Eu-F bond lengths and $\mathrm{Eu} \cdot \cdots \mathrm{Eu}$ distances are 2.328(13)-2.426(13) $\AA$ (mean $2.39 \AA$ ) and 3.9827(15)-4.0093(15) $\AA$ (mean $4.00 \AA$ ), respectively. The twelve octahedral edges of the central $\left[\mathrm{Eu}_{6} \mathrm{~F}_{8}\right]$ unit are coordinated by trifluoroacetato ligands in a bridging coordination mode (see Fig. 5a). Their $\mathrm{O}-\mathrm{C}-\mathrm{O}^{\prime}$ angles seem to be inhomogeneously ranging from $123(3)-132(2)^{\circ}$ (mean 127 $)$ but are nevertheless typical for the bidentate-bridging $\left(\mu_{2}-\mathrm{O}: \mathrm{O}^{\prime}\right)$ coordination mode. $130^{\circ}$ is usually found in lanthanoid(III) perfluorocarboxylates. ${ }^{12,13}$ Smaller $\mathrm{O}-\mathrm{C}-\mathrm{O}^{\prime}$ angles of about $120^{\circ}$ would be typical for the tridentate-chelating and -bridging $\left(\mu_{2}-\mathrm{O}: \mathrm{O}^{\prime}, \mathrm{O}\right)$ mode often found in lanthanoid(III) acetates. ${ }^{11}$ The six octahedral vertices of the central $\left[\mathrm{Eu}_{6} \mathrm{~F}_{8}\right]$ unit are coordinated by trifluoroacetic acid molecules, which form classical intramolecular $\mathrm{O}-\mathrm{H} \cdots \mathrm{O}$ hydrogen bonds with adjacent $\mu_{2-}$ $\mathrm{O}_{2} \mathrm{CCF}_{3}$ ligands (see Fig. 6a). The hydrogen bond motifs are self-contained and can be assigned to the graph set descriptor $S_{1}{ }^{1}(6) \cdot{ }^{34}$ The geometrical parameters of these hydrogen bonds are given in Table S3 (ESI $\dagger$ ). The very sharp band for the $\mathrm{O}-\mathrm{H}$ stretching mode in the IR spectrum of 2 at $3661 \mathrm{~cm}^{-1}$ strongly suggests that these hydrogen bonds are rather weak than strong, what would result in band broadening and a shift to smaller frequencies. ${ }^{35}$ The Eu-O distances involving the $\mathrm{O}$ atoms of the acid molecules at the octahedral vertices are slightly longer than those of the trifluoroacetato ligands at the octahedral edges, in the ranges of 2.528(17)-2.766(19) $\AA$ (mean $2.67 \AA$ ) and 2.337(18)-2.502(17) ̊ (mean $2.40 \AA$ ), respectively. $\mathrm{Six} \mathrm{Eu}^{3+}$ ions, eight fluoride ions, and twelve trifluoroacetate ions result in a double negatively charged complex ion. Charge compensation in the structure is ensured by two symmetry independent ammonium ions connecting the complex ions along the crystallographic $a$-axis.

Crystal structure of bis(ammonium) [dodecakis( $\mu_{2}$-pentafluoropropionato)hexakis( pentafluoropropionic acid)octa- $\mu_{3}$-fluorido-octahedro-hexaeuropiate(III)]-pentafluoropropionic acid (1/8), $\left(\mathrm{NH}_{4}\right)_{2}\left[\mathrm{Eu}_{6} \mathrm{~F}_{8}\left(\mathrm{O}_{2} \mathrm{CC}_{2} \mathrm{~F}_{5}\right)_{12}\left(\mathrm{C}_{2} \mathrm{~F}_{5} \mathrm{COOH}\right)_{6}\right] \cdot 8 \mathrm{C}_{2} \mathrm{~F}_{5} \mathrm{COOH}$ (3)

Compound 3 crystallizes in the monoclinic space group $P 2_{1} / n$ $(Z=4)$ and shows the same structural feature as 2 (see Fig. 4), particularly the same coordination pattern of the octahedral edges and vertices of the central $\left[\mathrm{Eu}_{6} \mathrm{~F}_{8}\right]$ unit as described for 2, with $\mathrm{C}_{2} \mathrm{~F}_{5}$ instead of $\mathrm{CF}_{3}$ as perfluoroalkyl groups (see 
(a)

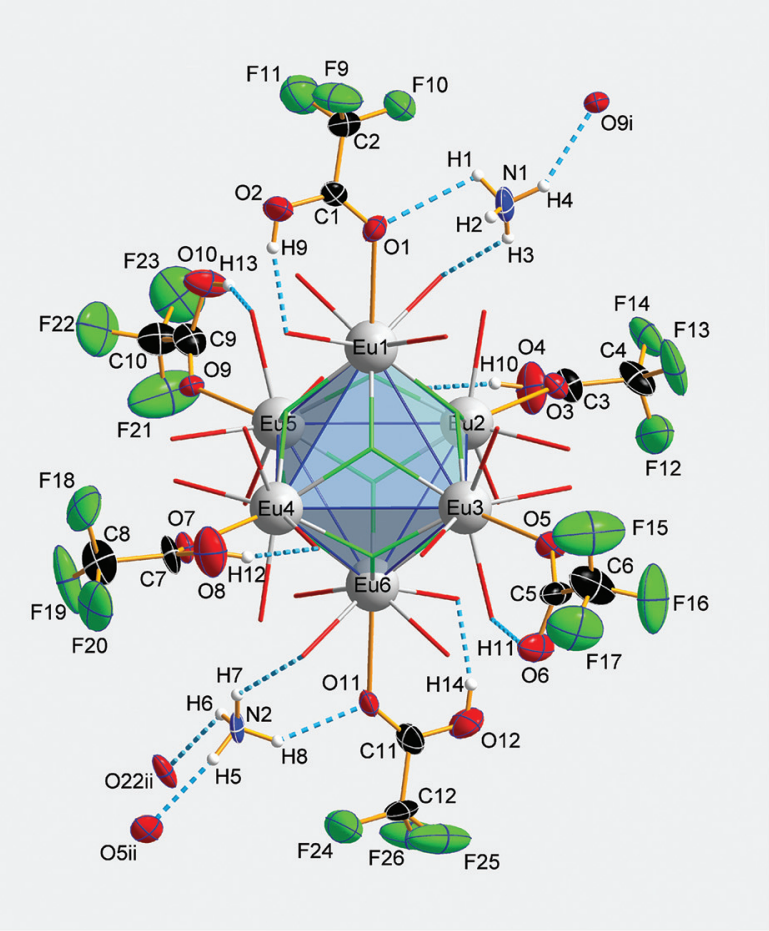

(b)

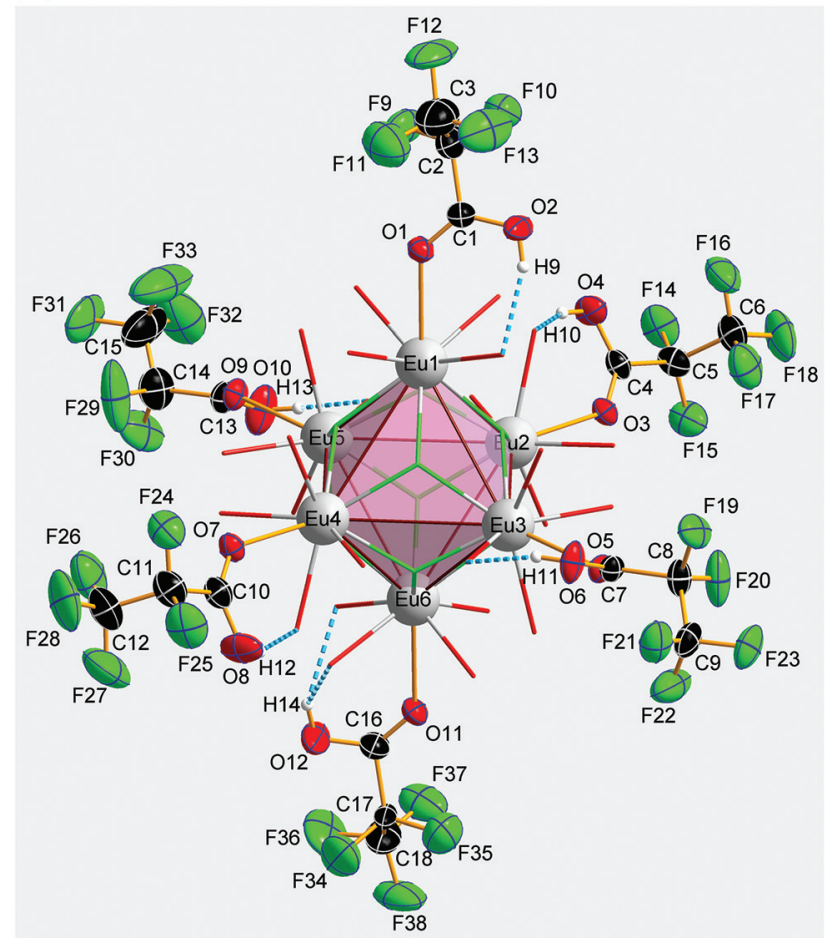

Fig. 6 Coordination of the octahedral vertices of the central $\left[\mathrm{Eu}_{6} \mathrm{~F}_{8}\right]$ units in 2 (part a) and 3 (part b). Displacement ellipsoids are drawn at the $50 \%$ probability level for the $\mathrm{NH}_{4}{ }^{+}$ions in 2, trifluoroacetic (pentafluoropropionic) acid, and the acceptors of hydrogen bonds (segmented sticks) as well. For the sake of clarity, the remaining parts of the structure are shown partially, in a combined wire and ball-and-stick (for Eu1-Eu6) model representation.

Fig. $5 \mathrm{~b}$ and $6 \mathrm{~b}$ ). The asymmetric unit $\mathrm{t}^{\star}$ of the crystal structure contains six $\mathrm{Eu}^{3+}$ ions, two $\mathrm{NH}_{4}{ }^{+}$ions (including N1, N2), eight fluoride ions (F1-F8), twelve pentafluoropropionate ions and fourteen molecules of pentafluoropropionic acid (all in general positions). The Eu‥Eu distances of 3.9537(4)-3.9978(5) $\AA$ (mean $3.98 \AA$ ) are in the same narrow range as those in 2 . The Eu-F bond lengths of 2.343(3)-2.417(3) $\AA$ (mean 2.37 $\AA$ ) are of the same magnitude, too. The $\mathrm{Eu}-\mathrm{O}$ bond lengths to the pentafluoropropionato ligands and to the vertex substituting acid molecules are in the ranges of 2.358(4)-2.494(4) $\AA$ (mean $2.40 \AA$ ) and 2.644(4)-2.701(4) A (mean 2.66 ̊), respectively. The $\mathrm{Eu}-\mathrm{F}$ and Eu-O bond lengths are given in Table S4 (ESI $\dagger$ ). The $\mathrm{O}-\mathrm{C}-\mathrm{O}^{\prime}$ angles are within the range of $126.6(8)-129.6(5)^{\circ}$. The fourteen molecules of pentafluoropropionic acid in the asymmetric unit of 3 can be divided into six internal ones that coordinate the octahedral vertices of the central $\left[\mathrm{Eu}_{6} \mathrm{~F}_{8}\right]$ unit and eight external molecules located in layer-like regions, that extend parallel to the $a, c$-plane at the heights 0 and $\frac{1}{2}$ of the unit cell. All of them, internal and external, are engaged in $\mathrm{O}-\mathrm{H} \cdots \mathrm{O}$ hydrogen bonds. Some of these are bifurcated, the great majority are simple ones. The geometrical parameters of all these and the hydrogen bonds of the two ammonium ions are given in Table S5 (ESI $\dagger$ ). The internal acid molecules at Eu1 to Eu5 form self-contained hydrogen bond patterns with adjacent $\mu_{2}-\mathrm{O}_{2} \mathrm{CC}_{2} \mathrm{~F}_{5}$ ligands in a manner already known from 2 (see Fig. 6b) [graph set descriptor $S_{1}^{1}(6)$ ]. The internal acid mole- cule at Eu6 forms a bifurcated hydrogen bond from $\mathrm{O} 12$ to $\mathrm{O} 33$ and $\mathrm{O} 35\left[R_{1}{ }^{2}(4)\right]$. The external acid molecules can be subdivided into four acid molecules that form single (O46, O48) or bifurcated (O50, O52) hydrogen bonds with peripheral ligands of the central $\left[\mathrm{Eu}_{6} \mathrm{~F}_{8}\right]$ unit $\left[D_{1}{ }^{1}(2)\right.$ or $\left.R_{1}{ }^{2}(4)\right]$, and four acid molecules that are associated to carboxylic acid dimers $\left[R_{2}{ }^{2}(8)\right]$ (see Fig. 7). The presence of these dimers as a particular structural feature is assumed to be related to the enlarged gaps between adjacent clusters, due to the enhanced perfluoroalkyl chain lengths of the peripheral ligands. The position of the hydrogen atoms can be clearly identified by aids of the $\mathrm{C}-\mathrm{O}$ bond lengths, which are about $0.1 \AA$ shorter for the $\mathrm{C}=\mathrm{O}$ bonds (mean $1.19 \AA$ ) than for the $\mathrm{C}-\mathrm{O}$ bonds (mean $1.29 \AA$ ). This is an expected feature of carboxylic acid dimers in the solid state except for aromatic carboxylic acids. ${ }^{36}$ The $\mathrm{O} \cdots \mathrm{O}$ distances of the dimers in 3 are in the range of 2.577(8)2.752(9) $\AA$ (mean $2.66 \AA$ ), which indicates medium-strength hydrogen bonds that are rather electrostatic than related to orbital interactions. ${ }^{37}$

The hydrogen bonds of the other external acid molecules are much weaker, with $\mathrm{O} \cdots \mathrm{O}$ distances of $2.902(6)-3.081(7) \AA$ (mean $2.99 \AA$ ). The $\mathrm{O} \cdots \mathrm{O}$ distances of the hydrogen bonds of the internal acid molecules are in the range of 2.669(6)-2.904(7) $\AA$ (mean $2.76 \AA$ ) and tend to be medium strong to weak. Among the small number of acid adducts of lanthanoid carboxylates, ${ }^{9 c, 11 f, 12 e, f}$ substances without bonds between the 

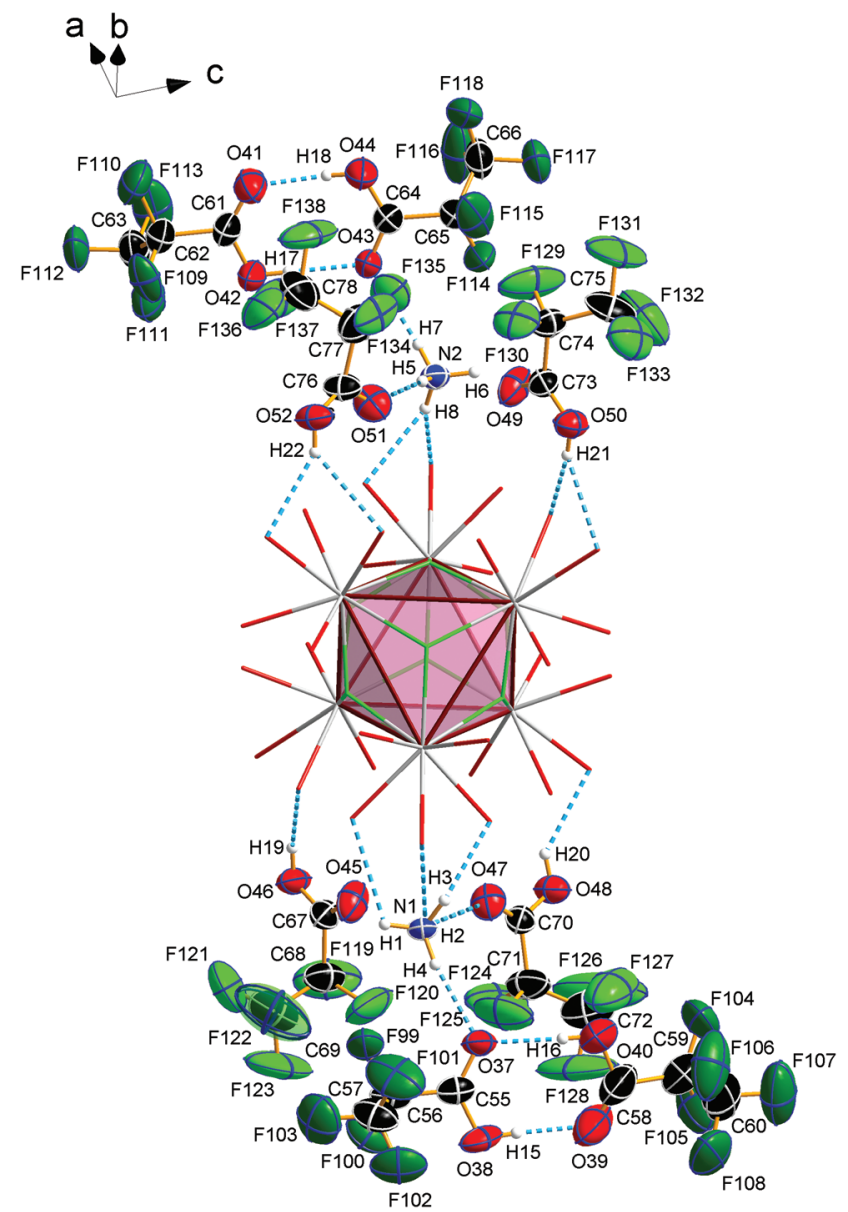

Fig. 7 Pentafluoropropionic acid molecules and dimers, located in layer-like regions, that extend parallel to the a,c-plane at the heights 0 and $\frac{1}{2}$ of the unit cell, $\mathrm{NH}_{4}{ }^{+}$ions and their hydrogen bond pattern (segmented sticks) in 3 . Displacement ellipsoids are drawn at the $50 \%$ probability level for the $\mathrm{NH}_{4}{ }^{+}$ions and pentafluoropropionic acid molecules. For the sake of clarity, the remaining parts of the structure are shown partially, in a wire model representation and $F$ atoms related to acid dimers are given in dark green.

carboxylic acid molecules to lanthanoid cations are rare and known only from unpublished results. ${ }^{38}$ The presence of carboxylic acid dimers has not yet been reported in the context of lanthanoid carboxylates. The $\mathrm{NH}_{4}^{+}$ion including $\mathrm{N} 1$ (N2) forms three (two) single and one bifurcated hydrogen bonds with external acid molecules and peripheral ligands of the central $\left[\mathrm{Eu}_{6} \mathrm{~F}_{8}\right]$ unit $\left[D_{1}{ }^{1}(2)\right.$ or $\left.R_{1}{ }^{2}(4)\right]$ (see Fig. 7). Since these acid molecules donate further hydrogen bonds to peripheral ligands at the central $\left[\mathrm{Eu}_{6} \mathrm{~F}_{8}\right]$ unit, the ammonium ions are part of an extended hydrogen bond network with maximum ring sizes according to graph set descriptors $R_{4}{ }^{3}(14)$ for $\mathrm{N} 1$ and $R_{3}{ }^{3}(12)$ for N2.

\section{Photoluminescence properties of 1, 2 and 3}

According to ${ }^{151} \mathrm{Eu}$ Mössbauer spectroscopy, the yellow crystals of 1 isolated from DMF contain a small amount of oxidation product (see Table 1). This is confirmed by luminescence spec- troscopic characterization. The barely visible luminescence of 1 under an UV lamp indicates that $\mathrm{Eu}^{\mathrm{III}}$ is present only as an impurity. The luminescence spectra confirm the findings from the Mössbauer spectroscopic measurements and reveal the typical $4 \mathrm{f}^{6} \leftrightarrow 4 \mathrm{f}^{6}$ transitions of Eu ${ }^{\mathrm{III}}$ (see Fig. 8c, left). ${ }^{39}$ The decay curve of $\mathbf{1}$ was fitted by a multiexponential function (see Fig. 8c, right) and luminescence decay times of $0.56(2) \mathrm{ms}$ (40.2\%) and 2.61(3) ms (60.8\%) were determined (see Table 2). These are typical for $\mathrm{Eu}^{\mathrm{III}}$ compounds with organic ligands and slightly shorter than those of inorganic $\mathrm{Eu}^{\mathrm{III}}$ doped fluorides, which have reported decay times of the ${ }^{5} D_{0}$ level as high


(c)
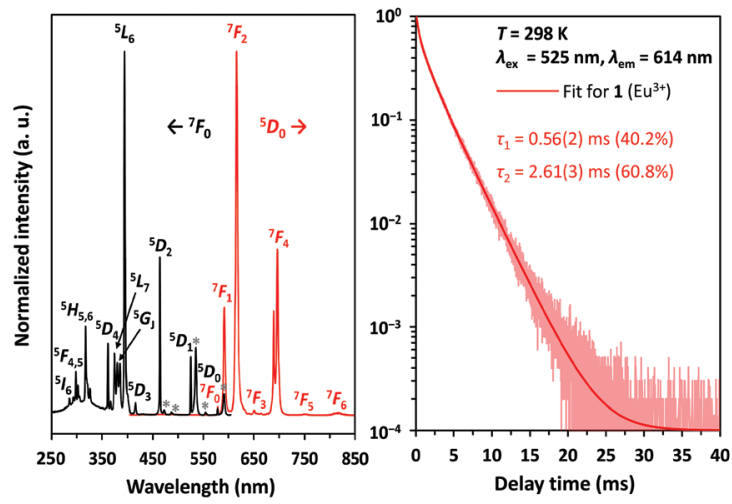

Fig. 8 (a) Absorption and emission bands of the coordination polymer 1; (b) luminescence decay of 1 at $\lambda_{\mathrm{em}}=450 \mathrm{~nm}$ (left) and $334 \mathrm{~nm}$ (right); (c) excitation and emission spectra of Eu'I impurities in 1 and luminescence decay of the level ${ }^{5} D_{0}$ at $\lambda_{\mathrm{em}}=614 \mathrm{~nm}$ and $298 \mathrm{~K}$; excitation lines marked with an asterisk indicate transitions from the thermally populated ${ }^{7} F_{J}(J=1,2)$ levels to the correspondingly labelled levels in the excitation spectrum. 
Table 2 Decay times of the Eu'll' luminescence of 1, 2 and 3, and reported lifetimes of polynuclear Eu ${ }^{\text {III }}$ hydroxido complexes

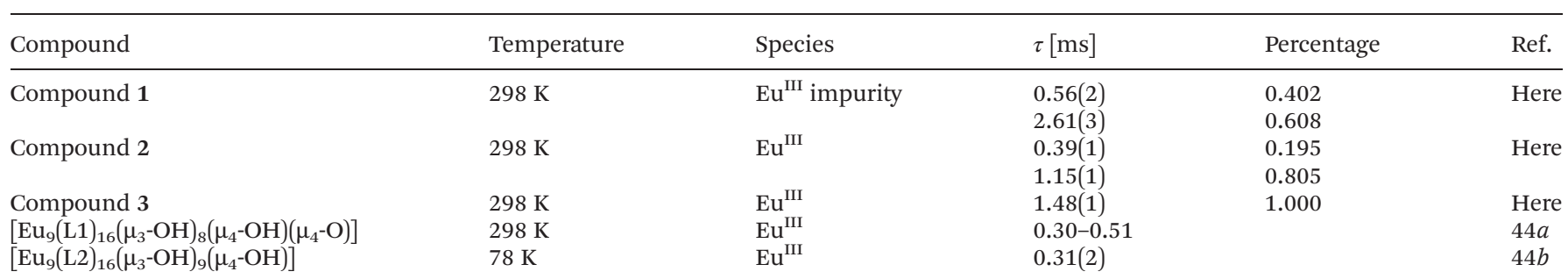

$\tau=$ luminescence decay time, $\mathrm{L} 1$ = (modified) 2-hydroxybenzophenone ligands; L2 = 9-hydroxyphenalen-1-one ligands.

as $10 \mathrm{ms.}^{40}$ At an excitation wavelength of $300 \mathrm{~nm}$, the broadband fluorescence of the organic ligands is prominent, showing an emission maximum at $334 \mathrm{~nm}$ (see Fig. 8a). This assignment is confirmed by the luminescence decay in the nanosecond range indicating fluorescence of the organic ligands (see Fig. 8b, right). Upon excitation at $380 \mathrm{~nm}$ a weak emission band with a maximum at $456 \mathrm{~nm}$ is detected, which could be assigned to the $4 \mathrm{f}^{6} 5 \mathrm{~d}^{1} \rightarrow 4 \mathrm{f}^{7}$ transition of Eu ${ }^{\mathrm{II}}$. However, the shortened luminescence decay time of less than $0.1 \mu$ s (see Fig. 8 b, left) is untypical for this transition, which is consistently reported in the order of $1 \mu \mathrm{s} .{ }^{41}$ Together with the low intensity of the emission band this suggests an effective quenching mechanism for the luminescence of $\mathrm{Eu}^{\mathrm{II}}$ at room temperature. Possible explanations are: (i) a small band gap of the coordination polymer, that induces thermal ionization of the excited $5 \mathrm{~d}$ electrons of $\mathrm{Eu}^{\mathrm{II}}$ into the conduction band. ${ }^{42}$ This may be supported by the bulk yellow color of $\mathbf{1}$ that indicates strong absorption of blue light; (ii) the presence of $\mathrm{Eu}^{\text {II }}$ next to $\mathrm{Eu}^{\mathrm{III}}$ allows energy transfer due to intervalence charge transfer (IVCT) processes; ${ }^{43}$ (iii) quenching of the luminescence due to non-radiative relaxation of the excited states by the vibration of DMF ligands. Future detailed studies of the photoluminescence at temperatures below $100 \mathrm{~K}$ could help provide additional insights into the quenching mechanism of the preliminarily assigned $\mathrm{Eu}^{\mathrm{II}}$-related blue luminescence at $458 \mathrm{~nm}$.

Compounds 2 and 3 show a very bright red luminescence under UV light (to get a better visual impression see Fig. 9d), typical for the $4 \mathrm{f}^{6} \leftrightarrow 4 \mathrm{f}^{6}$ transitions of $\mathrm{Eu}^{\mathrm{III}} .^{39}$ The photoluminescence spectra of 2 (see Fig. 9a) and 3 (see Fig. 9b) are consistent with this observation and show narrow lines in excitation and emission.

As expected, the emission originates from the ${ }^{5} \mathrm{D}_{0}$ level, since despite the low vibrational energies of the fluorinated organic ligands, emission from the ${ }^{5} \mathrm{D}_{1}$ or even ${ }^{5} \mathrm{D}_{2}$ level is unlikely. ${ }^{39}$ The most intense line in the excitation spectrum is related to the ${ }^{7} \mathrm{~F}_{0} \rightarrow{ }^{5} \mathrm{~L}_{6}$ transition at $394 \mathrm{~nm}$, while the emission spectrum is dominated by the ${ }^{5} \mathrm{D}_{0} \rightarrow{ }^{7} \mathrm{~F}_{2}$ transition at $614 \mathrm{~nm}$. Especially the much higher intensity of the strongly electric dipolar ${ }^{5} \mathrm{D}_{0} \rightarrow{ }^{7} \mathrm{~F}_{2}$ transition compared to the magnetic dipolar ${ }^{5} \mathrm{D}_{0} \rightarrow{ }^{7} \mathrm{~F}_{1}$ transition at $591 \mathrm{~nm}$ indicates that the $\mathrm{Eu}^{3+}$ ions are located in non-centrosymmetric positions. ${ }^{39}$ This is in agreement with the structural models of 2 and 3 . There is also no evidence for ligand-to-metal charge transfer (LMCT) transitions in the excitation spectrum. The decay curves of 2 and 3 were fitted by multiexponential functions (see Fig. 9c), giving luminescence decay times of $0.39(1) \mathrm{ms}$ (19.5\%) and 1.15(1) $\mathrm{ms}(80.5 \%)$ for 2 and 1.48(1) ms for 3 (see Table 3 ). These are typical for $\mathrm{Eu}^{\mathrm{III}}$ compounds with organic ligands and slightly shorter than those of inorganic Eu ${ }^{\mathrm{III}}$ doped fluorides, which have reported decay times of the ${ }^{5} \mathrm{D}_{0}$ level as high as $10 \mathrm{~ms} .{ }^{40}$ Interestingly, however, the lifetimes are longer than those of complexes with similar constructed $\left[\mathrm{Eu}_{9}(\mathrm{OH})_{n}\right]$ cores, ranging from $0.31(2) \mathrm{ms}\left(\left[\mathrm{Eu}_{9}(\mathrm{OH})_{10}\right]\right.$ core $)$ to $0.30-0.51 \mathrm{~ms}$ $\left(\left[\mathrm{Eu}_{9}(\mathrm{OH})_{9}(\mathrm{O})\right]\right.$ core $) .{ }^{44}$ Ling et al. observed that fluoride ions hardly contribute to non-radiative relaxation of the excited states of $\mathrm{Tb}^{\mathrm{III}}$ in a complex with a $\left[\mathrm{Tb}_{6} \mathrm{~F}_{8}\right]$ core due to their low vibrational energy and expanding the luminescence decay time compared to polynuclear terbium(III) hydroxido complexes. ${ }^{21}$ This is consistently confirmed for complexes with a $\left[\mathrm{Eu}_{6} \mathrm{~F}_{8}\right]$ core within this work.

\section{Experimental}

All experiments were performed on a vacuum line equipped with J. Young high-vacuum PTFE valves under an inert argon atmosphere, unless otherwise stated. Liquid ammonia for the syntheses was freshly condensed and dried over sodium before use. Perfluorocarboxylic acids were distilled with 10 vol\% of the corresponding anhydride over a $20 \mathrm{~cm}$ Vigreux column and kept under argon. The hygroscopic salts ammonium trifluoroacetate and pentafluoropropionate were handled in an argon filled glovebox. All other chemicals were obtained from commercial sources and used as purchased.

\section{Synthesis of catena-poly[europium(II)bis $\left(\mu_{2}-N, N\right.$-dimethyl- formamide $)$ bis $\left(\mu_{2}\right.$-trifluoroacetato $\left.)\right],\left[\mathrm{Eu}\left(\mathrm{O}_{2} \mathrm{CCF}_{3}\right)_{2}(\mathrm{dmf})_{2}\right]_{\infty}(1)$}

$0.684 \mathrm{~g}(4.50 \mathrm{mmol})$ of europium was weighed in a reaction vessel containing a glass-coated stir bar and dissolved in $50 \mathrm{ml}$ of dried liquid ammonia. $1.179 \mathrm{~g}$ (9.90 mmol) of ammonium trifluoroacetate was added to the dark blue solution. The resulting yellow suspension was stirred for $1 \mathrm{~h}$ at approximately $-30{ }^{\circ} \mathrm{C}$. The ammonia was evaporated, and the residue dried in vacuum for $8 \mathrm{~h}$ until a pressure of $10^{-3} \mathrm{hPa}$ was reached. The residue was ground to a fine yellow powder $(1.30 \mathrm{~g}) .{ }^{151} \mathrm{Eu}$ Mössbauer spectrum, isomer shift $\left[\mathrm{mm} \mathrm{s}^{-1}\right]$ : $\mathrm{Eu}^{\mathrm{III}}$ : 0.35 (23\%), $\mathrm{Eu}^{\mathrm{II}}$ : -13.11 (77\%). $400 \mathrm{mg}$ of this crude product were stirred in an ampoule with $4 \mathrm{ml}$ of DMF and the 

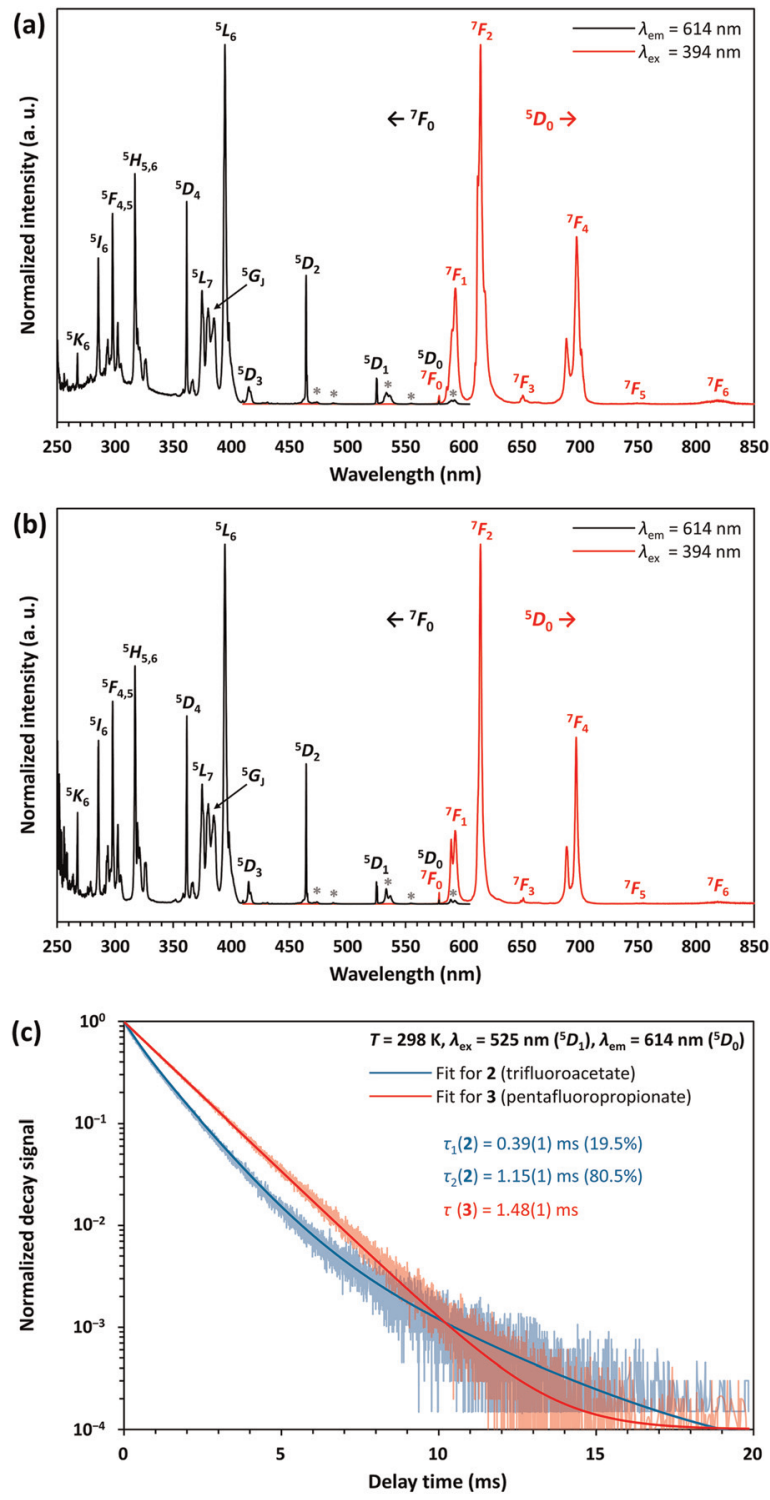

(d)
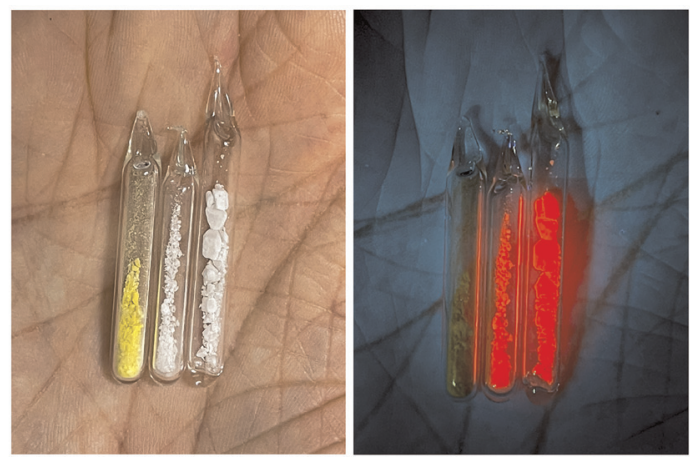

Fig. 9 Excitation (black) and emission (red) spectra of the compounds 2 (a) and 3 (b); excitation lines marked with an asterisk indicate transitions from the thermally populated ${ }^{7} F_{J}(J=1,2)$ levels to the correspondingly labelled levels in the excitation spectrum; (c) luminescence decay of the level ${ }^{5} D_{0}$ and fits for 2 and 3 at $\lambda_{\mathrm{em}}=614 \mathrm{~nm}$ and $298 \mathrm{~K}$; (d) compounds 1, 2 and 3 in daylight (left) and under an UV lamp with an emission maximum of $265 \mathrm{~nm}$ (right). The samples were placed in closed tubes after drying in vacuum. insoluble part was allowed to settle overnight. The supernatant yellow solution was transferred into another ampoule and DMF was distilled off in vacuo until the solution was concentrated to half of its initial volume. The ampoule, sealed with a PTFE ring seal, was stored at $8{ }^{\circ} \mathrm{C}$. Within 1-2 weeks hair-fine yellow crystal needles of $\mathbf{1}$ grew, which rapidly redissolve at room temperature. The crystalline material was dried in vacuum to a pressure of $5 \times 10^{-3} \mathrm{hPa}$. Yield: $0.230 \mathrm{~g}, 43 \%$ based on Eu. Elemental analysis [\%]: Found: C, 20.8; H, 2.3; N, 5.0; Eu, 31.6. Calc. for $\mathrm{C}_{10} \mathrm{H}_{14} \mathrm{~N}_{2} \mathrm{O}_{6} \mathrm{~F}_{6}$ Eu: C, 22.91; H, 2.69; N, 5.34; $\mathrm{Eu}, 28.99$. IR spectrum $\left[\mathrm{cm}^{-1}\right]: \nu_{\text {as }}(\mathrm{COO}): 1638$ (s); $\nu_{\mathrm{s}}(\mathrm{COO}): 1482(\mathrm{~m}) ; \nu(\mathrm{C}-\mathrm{F}): 1200,1160(\mathrm{~s}) ; \nu(\mathrm{C}-\mathrm{C}): 854(\mathrm{w})$; $\delta\left(\mathrm{CF}_{3}\right): 800(\mathrm{~m}) ; \delta(\mathrm{O}-\mathrm{C}-\mathrm{O}): 723(\mathrm{~m}) ; \delta\left(\mathrm{CF}_{3}\right): 610,520,450(\mathrm{w})$. Bands caused by DMF: $\nu(\mathrm{C}-\mathrm{H}): 2942(\mathrm{w}) ; \nu(\mathrm{C}=\mathrm{O}): 1713(\mathrm{~m})$; $\nu(\mathrm{C}-\mathrm{N}) 1500(\mathrm{w}) ; \delta\left(\mathrm{N}-\mathrm{CH}_{3}\right): 1438,1427(\mathrm{w}) ; \delta\left(\mathrm{CH}_{3}\right): 1379(\mathrm{~m})$; $1351(\mathrm{vw}) ; \nu\left(\mathrm{N}-\mathrm{CH}_{3}\right): 1256(\mathrm{vw}) ; \gamma\left(\mathrm{N}-\mathrm{CH}_{3}\right): 1110(\mathrm{~m}) ; \delta\left(\mathrm{CH}_{3}\right)$ : $1061(\mathrm{w}) ; \delta(\mathrm{O}=\mathrm{C}-\mathrm{N}): 678(\mathrm{w})$. Raman spectrum $\left[\mathrm{cm}^{-1}\right]: 2947$ (s); $\nu_{\text {as }}(\mathrm{COO}): 1660(\mathrm{w}) ; \nu_{\mathrm{s}}(\mathrm{COO}): 1462(\mathrm{~s}) ; \delta\left(\mathrm{CF}_{3}\right): 1205(\mathrm{w}) ; 933$ (w); $\nu(\mathrm{C}-\mathrm{C}): 850(\mathrm{~s}), \delta(\mathrm{O}-\mathrm{C}-\mathrm{O}): 733(\mathrm{~m}) ; \delta\left(\mathrm{CF}_{3}\right): 600(\mathrm{~m}), 520$ $(\mathrm{w}), 417(\mathrm{~s}) ; 270(\mathrm{~m}) ; 85(\mathrm{~s}) .{ }^{19} \mathrm{~F}$ NMR spectrum $(282.38 \mathrm{MHz}$, $\left.\mathrm{D}_{2} \mathrm{O} / \mathrm{NaOH}\right)[\mathrm{ppm}]:-75.2\left(\mathrm{~s}, \mathrm{CF}_{3}\right) .{ }^{151} \mathrm{Eu}$ Mössbauer spectrum, isomer shift $\left[\mathrm{mm} \mathrm{s}^{-1}\right]$ : $\mathrm{Eu}^{\mathrm{III}}$ : $0.31(12 \%), \mathrm{Eu}^{\mathrm{II}}:-13.33(88 \%)$.

Synthesis of bis (ammonium)[dodecakis( $\mu_{2}$-trifluoroacetato)hexakis(trifluoroacetic acid)octa- $\mu_{3}$-fluorido-octahedrohexaeuropiate(II)], $\left(\mathrm{NH}_{4}\right)_{2}\left[\mathrm{Eu}_{6} \mathrm{~F}_{8}\left(\mathrm{O}_{2} \mathrm{CCF}_{3}\right)_{12}\left(\mathrm{CF}_{3} \mathrm{COOH}\right)_{6}\right]$ (2)

Preparation and crystallization of $\mathbf{2}$ was as described for $\mathbf{1}$ using $150 \mathrm{mg}$ of the crude product obtained from liquid ammonia and $3 \mathrm{ml}$ of anhydrous trifluoroacetic acid instead of DMF. The mother liquor was removed, and the crystalline material dried in vacuo until a pressure of $10^{-2} \mathrm{hPa}$ was reached. Yield: $81 \mathrm{mg}, 31 \%$ based on Eu. A coulometric Karl Fischer titration of the mother liquor gave a water content of 1.9\%. Elemental analysis [\%]: Found: C, 13.9; H, 0.6; N, 1.1; $\mathrm{Eu}$, 29.4. Calc. for $\mathrm{C}_{36} \mathrm{H}_{14} \mathrm{~N}_{2} \mathrm{O}_{36} \mathrm{~F}_{62} \mathrm{Eu}_{6}: \mathrm{C}, 13.76 ; \mathrm{H}, 0.45 ; \mathrm{N}$, 0.89; $\mathrm{Eu}, 29.04$. IR spectrum $\left[\mathrm{cm}^{-1}\right]: \nu(\mathrm{O}-\mathrm{H}): 3661(\mathrm{~m}), 3500$ (w); $\nu\left(\mathrm{N}-\mathrm{H}, \mathrm{NH}_{4}{ }^{+}\right): 3190,3072,2963(\mathrm{w}) ; \nu(\mathrm{C}=\mathrm{O}): 1755,1725$ (m); $\nu_{\text {as }}(\mathrm{COO}): 1670(\mathrm{~s}) ; 1600(\mathrm{~s}) ; \nu_{\mathrm{s}}(\mathrm{COO}): 1477(\mathrm{~m}) ; \delta(\mathrm{O}-\mathrm{H}):$ 1424 (w, sh); $\nu(\mathrm{C}-\mathrm{F}): 1199,1155$ (s); $\gamma(\mathrm{O}-\mathrm{H}): 877$ (w); $\nu(\mathrm{C}-\mathrm{C}):$ $844(\mathrm{w}) ; \delta\left(\mathrm{CF}_{3}\right): 800(\mathrm{~m}) ; 737(\mathrm{w}) ; \delta(\mathrm{O}-\mathrm{C}-\mathrm{O}): 719(\mathrm{~m}) ; 701(\mathrm{w}) ;$ $\delta\left(\mathrm{CF}_{3}\right): 612,521,443(\mathrm{w})$. Raman spectrum $\left[\mathrm{cm}^{-1}\right]: \nu(\mathrm{C}=\mathrm{O})$ : $1716(\mathrm{~m}) ; \nu_{\mathrm{as}}(\mathrm{COO}): 1660(\mathrm{~m}) ; 1600(\mathrm{w}) ; \nu_{\mathrm{s}}(\mathrm{COO}): 1473(\mathrm{~s}) ; \nu(\mathrm{C}-$ F): $1205(\mathrm{~m}) ; \nu(\mathrm{C}-\mathrm{C}): 850(\mathrm{~s}) ; 835(\mathrm{~s}) ; 775(\mathrm{~m}) ; 741(\mathrm{~s}) ; \delta\left(\mathrm{CF}_{3}\right)$ : $613(\mathrm{~m}), 548(\mathrm{w}) ; 440(\mathrm{~m}) ; 363(\mathrm{w}) ; 285(\mathrm{~m}) ; 93(\mathrm{~s}) .{ }^{19} \mathrm{~F} \mathrm{NMR}$ spectrum $\left(282.38 \mathrm{MHz}, \mathrm{D}_{2} \mathrm{O} / \mathrm{NaOH}\right)[\mathrm{ppm}]:-75.5\left(\mathrm{~s}, \mathrm{CF}_{3}\right)$; -122.5 (s, $\left.\mathrm{F}^{-}\right) .{ }^{151} \mathrm{Eu}$ Mössbauer spectrum, isomer shift $[\mathrm{mm}$ $\left.\mathrm{s}^{-1}\right]: \mathrm{Eu}^{\mathrm{III}}: 0.18$.

Synthesis of bis(ammonium)[dodecakis $\left(\mu_{2}\right.$-pentafluoro-propionato)hexakis(pentafluoropropionic acid)octa- $\mu_{3}$-fluorido-octahedro-hexaeuropiate(III)] - pentafluoropropionic acid (1/8), $\left(\mathrm{NH}_{4}\right)_{2}\left[\mathrm{Eu}_{6} \mathrm{~F}_{8}\left(\mathrm{O}_{2} \mathrm{CC}_{2} \mathrm{~F}_{5}\right)_{\mathbf{1 2}}\left(\mathrm{C}_{2} \mathrm{~F}_{5} \mathbf{C O O H}\right)_{6}\right] \cdot 8 \mathrm{C}_{2} \mathrm{~F}_{5} \mathbf{C O O H}$ (3)

$10 \mathrm{ml}\left(50.7 \mathrm{mmol}, \rho_{25}=1.571 \mathrm{~g} \mathrm{~cm}^{-3}\right)$ of pentafluoropropionic anhydride was slowly mixed with $95 \%$ of the $1: 1$ molar ratio of water $(0.87 \mathrm{ml}, 48.2 \mathrm{mmol})$ in a microdistillation device under ice cooling. The liquid was distilled over a $10 \mathrm{~cm}$ 
Table 3 Crystal data and structure refinement parameters for 1, 2 and 3

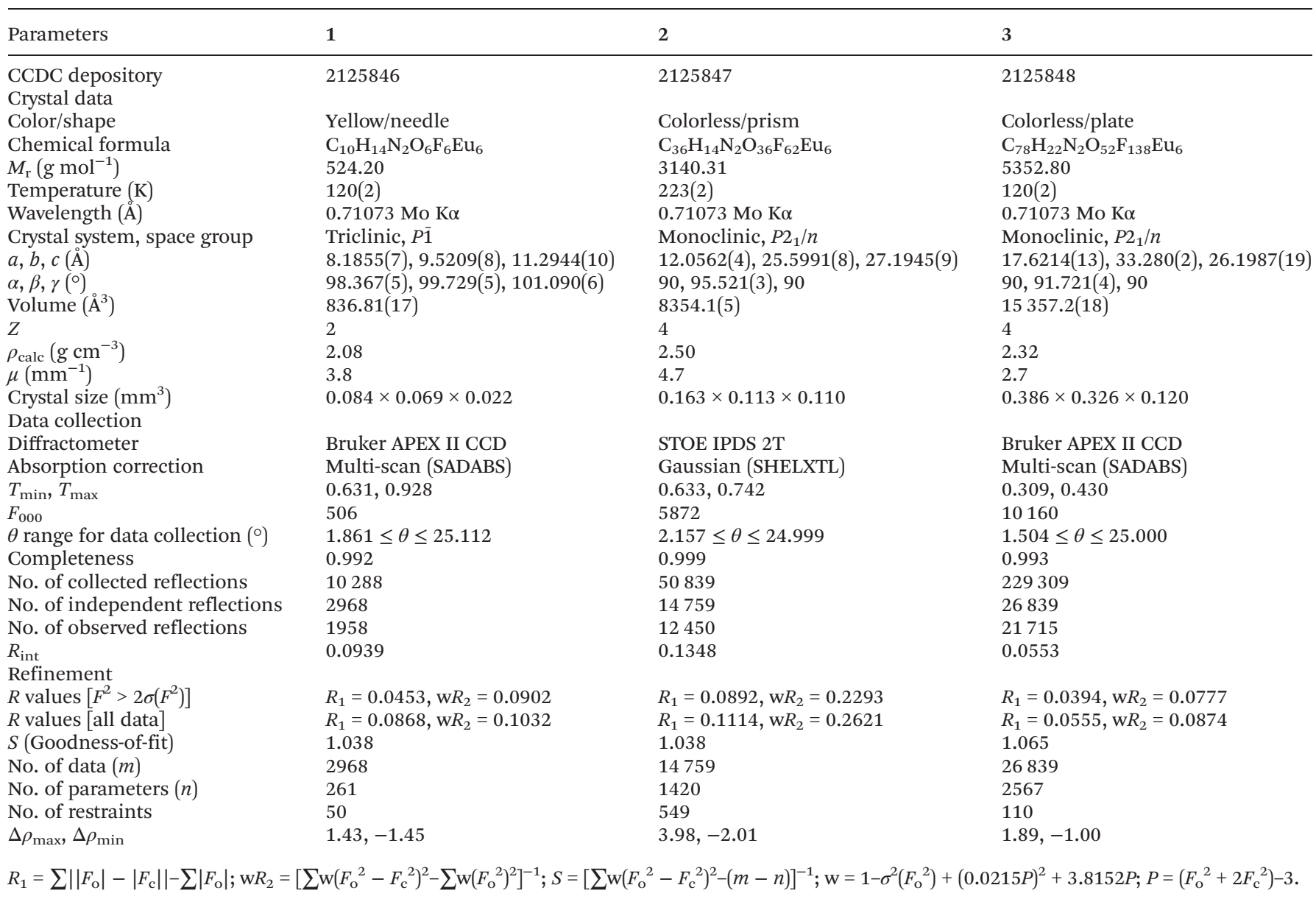

Vigreux column, and the main fraction collected at $96-97^{\circ} \mathrm{C}$. $0.89 \mathrm{ml}\left(8.4 \mathrm{mmol}, \rho_{25}=1.561 \mathrm{~g} \mathrm{~cm}^{-3}\right)$ of the pentafluoropropionic acid was slowly dropped into a reaction vessel containing a glass-coated stir bar to $50 \mathrm{ml}$ of dried liquid ammonia. $0.638 \mathrm{~g}(4.2 \mathrm{mmol})$ of europium was added. The resulting yellow suspension was stirred for $1 \mathrm{~h}$ at approximately $-30^{\circ} \mathrm{C}$. The ammonia was evaporated, and the residue dried in vacuum for $8 \mathrm{~h}$ until a pressure of $10^{-3} \mathrm{hPa}$ was reached. The residue was ground to a fine yellow powder $(1.12 \mathrm{~g}) .{ }^{151} \mathrm{Eu}$ Mössbauer spectrum, isomer shift $\left[\mathrm{mm} \mathrm{s}^{-1}\right]$ : $\mathrm{Eu}^{\mathrm{III}}: 0.29$ (50\%); $\mathrm{Eu}^{\mathrm{II}}$ : $-13.11(50 \%)$. Crystals of 3 were received as described for 1 using $230 \mathrm{mg}$ of this crude product and $3 \mathrm{ml}$ of anhydrous pentafluoropropionic acid instead of DMF. The mother liquor was removed, and the crystalline material dried in vacuo until a pressure of $10^{-2} \mathrm{hPa}$ was reached. Yield: $163 \mathrm{mg}, 28 \%$ based on Eu. A coulometric Karl Fischer titration gave a water content of the mother liquor of $0.95 \%$. Elemental analysis [\%]: Found: $\mathrm{C}, 16.4 ; \mathrm{H}, 0.4 ; \mathrm{N}, 0.7 ; \mathrm{Eu}, 21.1$. Calc. for 3-8 $\mathrm{C}_{2} \mathrm{~F}_{5} \mathrm{COOH}, \mathrm{C}_{54} \mathrm{H}_{14} \mathrm{~N}_{2} \mathrm{O}_{36} \mathrm{~F}_{98} \mathrm{Eu}_{6}: \mathrm{C}, 16.05 ; \mathrm{H}, 0.35 \mathrm{~N}, 0.69$; Eu, 22.57. IR spectrum $\left[\mathrm{cm}^{-1}\right]: \nu(\mathrm{O}-\mathrm{H}): 3602(\mathrm{w}), 3538(\mathrm{vw})$; $\nu(\mathrm{C}=\mathrm{O}): 1775(\mathrm{w}) ; \nu_{\text {as }}(\mathrm{COO}): 1693(\mathrm{~s}) ; 1625(\mathrm{w}) ; \nu_{\mathrm{s}}(\mathrm{COO}): 1439$ (m); $\nu\left(\mathrm{CF}_{3}-\mathrm{CF}_{2}\right): 1328(\mathrm{~m}) ; \nu(\mathrm{C}-\mathrm{F}): 1213(\mathrm{~m}), 1159$ (s); $\nu\left(\mathrm{CF}_{2}{ }^{-}\right.$ COO): $1032(\mathrm{~s}) ; \delta(\mathrm{C}-\mathrm{C}): 821(\mathrm{w}) ; \delta(\mathrm{O}-\mathrm{C}-\mathrm{O}): 729(\mathrm{~m}) ; \delta\left(\mathrm{CF}_{3}\right): 584$,
539 (w); 407 (w). Raman spectrum [ $\left.\mathrm{cm}^{-1}\right]: \nu(\mathrm{C}=\mathrm{O}): 1776(\mathrm{w})$; $\nu_{\text {as }}(\mathrm{COO}): 1709(\mathrm{~s}) ; \nu_{\mathrm{s}}(\mathrm{COO}): 1442(\mathrm{~s}) ; \nu\left(\mathrm{CF}_{3}-\mathrm{CF}_{2}\right): 1332(\mathrm{w}) ;$ $\nu(\mathrm{C}-\mathrm{F}): 1218(\mathrm{w}), \nu\left(\mathrm{CF}_{2}-\mathrm{COO}\right): 1039(\mathrm{w}) ; \delta(\mathrm{C}-\mathrm{C}): 826(\mathrm{~s}) ; 779(\mathrm{~s}) ;$ $\delta(\mathrm{O}-\mathrm{C}-\mathrm{O}): 739(\mathrm{~m}) ; 624(\mathrm{w}) ; \delta\left(\mathrm{CF}_{3}\right): 584,542(\mathrm{w}) ; 426(\mathrm{~s}) ; 394$ (s); 361 (s); 295 (m); 143, 118, 78 (s). ${ }^{19} \mathrm{~F}$ NMR spectrum $\left(282.38 \mathrm{MHz}, \mathrm{CD}_{3} \mathrm{CN} / \mathrm{NaOH}\right)[\mathrm{ppm}]:-76.9\left(\mathrm{~s}, \mathrm{~F}^{-}\right) ;-84.1(\mathrm{~s}$, $\left.\mathrm{CF}_{3}\right) ;-123.1\left(\mathrm{~s}, \mathrm{CF}_{2}\right) \cdot{ }^{151} \mathrm{Eu}$ Mössbauer spectrum, isomer shift $\left[\mathrm{mm} \mathrm{s}^{-1}\right]: \mathrm{Eu}^{\mathrm{III}}: 0.31$.

\section{Crystallography}

Crystals of 1, 2 and 3 suitable for crystal structure analysis were selected in perfluorinated oil and mounted in the nitrogen-cold gas stream on a STOE IPDS $2 \mathrm{~T}$ diffractometer in the case of 2 and on a Bruker APEX II CCD diffractometer in the cases of $\mathbf{1}$ and 3. Indexing, unit cell refinement, data collection and data processing were performed using X-AREA ${ }^{45}$ or APEX $2{ }^{46}$ A Gaussian absorption correction was applied for 2 with the XPREP routine of SHELXTL and a multi-scan absorption correction was applied for $\mathbf{1}$ and $\mathbf{3}$ with SADABS. The structures were solved by Direct Methods and refined by fullmatrix least-squares calculations on $F^{2}$ with programs of the SHELX system. ${ }^{47}$ All non-hydrogen atoms were located and all $\mathrm{H}$ atoms were included in idealized positions. For those $\mathrm{H}$ 
atoms bound to $\mathrm{C}$ and $\mathrm{O}$ a riding model was applied, with bond lengths constrained to 0.98, 0.95 and $0.83 \AA$ for $\mathrm{CH}_{3}, \mathrm{CH}$ and $\mathrm{OH}$ groups, respectively. In addition, the $\mathrm{CH}_{3}$ groups and the $\mathrm{OH}$ groups were allowed to rotate around the adjacent $\mathrm{N}-\mathrm{C}$ and $\mathrm{O}-\mathrm{C}$ bond, respectively. The $\mathrm{NH}_{4}{ }^{+}$ions in 2 and 3 were included in the refinement as rigid groups with idealized tetrahedral geometry and $\mathrm{N}-\mathrm{H}$ bond lengths constrained to $0.91 \AA$. The displacement parameters $U_{\text {iso }}(\mathrm{H})$ were set to $1.5 U_{\text {eq }}$, $1.5 U_{\text {eq }}, 1.5 U_{\text {eq }}$ and $1.2 U_{\text {eq }}$ of the parent atoms for $\mathrm{OH}, \mathrm{NH}, \mathrm{CH}_{3}$ and $\mathrm{CH}$, respectively. For trifluoromethyl groups in $\mathbf{1}$ and 2, clearly identified as disordered, partial occupation site models were introduced. In the final stages of converging refinements, the corresponding site occupation factors refined to 0.556(14):0.444(14) and 0.58(5):0.42(5)-0.66(5):0.34(5) for 1 and 2, respectively. Partial occupation site models were introduced for disordered pentafluoroethyl groups in 3, giving site occupation factors of $0.548(8): 0.452(8)-0.821(5): 179(5)$ in course of the refinement. Crystals of 2 notoriously suffer from twinning and the plane law (1 $\left.\begin{array}{lll}1 & 0 & 0\end{array}\right)$ was detected by closer inspection. Based on the entire set of intensity data from both individuals and assuming the additivity of intensities for overlapped reflections a refinement with the HKLF5 option of SHELXL was performed. However, several shortcomings of the refinement including convergence problems forced us to discard this attempt. Tolerating some feature in the residual electron density map, definitely related to the twinning, a refinement based on intensities collected with the orientation matrix of the main individual and applying the index-transforming twin

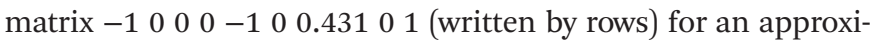
mate treatment of the intensity contamination resulting from the twinning and applying symmetry merging as well gave the best result in terms of plausibility of geometric parameters and anisotropic atom displacement. The fraction of second individual contribution was refined to 0.252(2). Molecular graphics were generated with DIAMOND. ${ }^{48}$ Crystal data, data collection and structure refinement details for 1, 2 and 3 are given in Table 3.

\section{Elemental analysis}

The elemental analyses were performed using a vario MICRO cube (Elementar Analysensysteme $\mathrm{GmbH}){ }^{49}$ They were supplemented by the determination of the europium content using a titrimetric method. ${ }^{19,50} 50-150 \mathrm{mg}$ of the sample was weighed to the nearest $0.1 \mathrm{mg}$ and dissolved in $10 \mathrm{ml}$ of hydrochloric acid, $c(\mathrm{HCl})=6 \mathrm{~mol}^{-1}$. This solution was diluted to $60 \mathrm{ml}$ with water and dropped into a chromatography column of $2 \mathrm{~cm}$ diameter, filled with a $20 \mathrm{~cm}$ high layer of zinc amalgam containing $1 \%$ of mercury. ${ }^{51}$ The solution was collected in a flask containing $15 \mathrm{ml}$ of $\mathrm{FeCl}_{3}-\mathrm{H}_{2} \mathrm{SO}_{4}$ reagent [dissolve $2.70 \mathrm{~g}$ of $\mathrm{FeCl}_{3} \cdot 6 \mathrm{H}_{2} \mathrm{O}$ in $100 \mathrm{ml}$ sulfuric acid, $c\left(\mathrm{H}_{2} \mathrm{SO}_{4}\right)=$ $\left.1 \mathrm{~mol} \mathrm{l}^{-1}\right]$ and two drops of ferroin solution $\left(1 / 40 \mathrm{~mol} \mathrm{l}^{-1}\right)$. To exclude atmospheric oxygen, a steady stream of dry nitrogen was passed through the flask. After the solution completely passed the reducer, it was washed with $40 \mathrm{ml}$ of hydrochloric acid, $c(\mathrm{HCl})=0.1 \mathrm{~mol} \mathrm{l}^{-1}$, and the content of the flask (no longer under inert gas) was acidified with $2 \mathrm{ml}$ conc. phospho- ric acid and titrated with a solution of cerium(Iv) sulfate, $c[1 / 1$ $\left.\mathrm{Ce}\left(\mathrm{SO}_{4}\right)_{2}\right]=0.05 \mathrm{~mol} \mathrm{l}^{-1}$, until the colour changed from orange to blue. Since the end point is indicated with some delay, the titration must be carried out very slowly towards the end. To take into account remaining dissolved oxygen, negatively influencing the results, the standard solution was adjusted against portions of europium(III) oxide.

\section{${ }^{151}$ Eu Mössbauer spectroscopy}

For ${ }^{151} \mathrm{Eu}$ Mössbauer spectroscopic studies on the compounds 1, 2 and 3, and their corresponding precursors the $21.53 \mathrm{keV}$ transition of a ${ }^{151} \mathrm{Sm}: \mathrm{EuF}_{3}$ source with an activity of $55 \mathrm{MBq}$ ( $1 \%$ of the total source activity) was used in normal transmission geometry. The samples were investigated with a commercial liquid nitrogen bath cryostat $(78 \pm 0.5 \mathrm{~K}$, for 1,2 and 3) or with a Janis Research continuous flow helium cryostat ( $6 \pm$ $0.5 \mathrm{~K}$, for the precursors). The samples were cooled to the respective temperature while the source was kept at room temperature. The temperatures were controlled with a resistance thermometer. The samples were prepared by mixing them with $\alpha$-quartz in an argon-filled glovebox and placing them in a thin-walled PMMA container, $2 \mathrm{~cm}$ in diameter. These were then rapidly glued airtight outside the glovebox. The absorber thickness was calculated so that it corresponded to $10 \mathrm{mg}$ of europium per $\mathrm{cm}^{2}$ of the sample holder. The results were fitted and plotted with the WinNormos for Igor6 program package ${ }^{52}$ and graphical editing was done with CorelDraw $2017 .^{53}$

\section{Photoluminescence spectroscopy}

Steady-state and time-resolved photoluminescence studies on the powdered compounds 1, 2 and 3 were performed on an FLS1000 photoluminescence spectrometer from Edinburgh Instruments equipped with a $450 \mathrm{~W}$ Xe arc lamp as an excitation source, double excitation and emission monochromators (focal length $2 \times 325 \mathrm{~mm}$ ) in Czerny Turner configuration and a thermoelectrically cooled $\left(-20^{\circ} \mathrm{C}\right)$ photomultiplier tube PMT-980 as a detector. All spectra and decay traces were measured at room temperature. Emission spectra were corrected with respect to the grating efficiency and PMT sensitivity, while excitation spectra were additionally corrected with respect to the lamp intensity. Fluorescence decay traces (delay time ranges $<1 \mu \mathrm{s}$ ) were measured with pulsed laser diodes from Edinburgh Instruments (EPL-320 for excitation at $320 \mathrm{~nm}$, EPL-375 for excitation at $375 \mathrm{~nm}$, temporal pulse widths: $\sim 75 \mathrm{ps}$ ) and time-correlated single photon detection, while longer decay traces (delay time ranges $>1 \mu \mathrm{s}$ ) were acquired using a $\mu \mathrm{F} 2$ Xe flash lamp $(150 \mathrm{~W})$ with an average pulse width of $2 \mu$ s and single-photon multi-channel scaling detection.

\section{IR and Raman spectroscopy}

Compounds 1, 2 and 3, and their corresponding precursors were characterized via vibrational spectroscopy. IR spectra were recorded with a PerkinElmer Spectrum Two FT-IR spectrometer equipped with a $\mathrm{LiTaO}_{3}$ detector 
$\left(4000-350 \mathrm{~cm}^{-1}\right)$ and an universal ATR unit. ${ }^{54}$ Raman spectra were recorded with a Bruker MultiRAM spectrometer equipped with a Nd:YAG laser $(1064 \mathrm{~nm})$ and an InGaAs detector $\left(4000-70 \mathrm{~cm}^{-1}\right) .{ }^{55}$ Band assignments for 1 were made using the IR spectra of $\mathrm{DMF}^{56}$ and metal trifluoroacetates, ${ }^{57}$ for 2 additionally of trifluoroacetic acid ${ }^{35}$ and trifluoroacetic acid esters $^{58}$ and for 3 of pentafluoropropionic acid ${ }^{59}$ and some of its esters. ${ }^{60}$

\section{${ }^{19}$ F NMR spectroscopy}

Compounds 2 and 3 were characterized via ${ }^{19} \mathrm{~F}$ NMR spectroscopy. $10-20 \mathrm{mg}$ each were dissolved in $0.7 \mathrm{ml} \mathrm{D}_{2} \mathrm{O}$ (for 2) or $\mathrm{CD}_{3} \mathrm{CN}$ (for 3 ) and the ${ }^{19} \mathrm{~F}$ NMR spectra were recorded using a Bruker Avance III spectrometer at 282.38 MHz. The fluoride ions bound to europium were released by adding a drop of conc. $\mathrm{NaOH}$ solution to the NMR tube and a second spectrum was recorded. Due to the poor solubility of some $\mathrm{EuF}_{3}$ precipitated a qualitative detection of the fluoride ions is possible, only.

\section{Karl Fischer titration}

The water content in the mother liquors from the crystallization of $\mathbf{2}$ and $\mathbf{3}$ was determined by coulometric Karl Fischer titrations. $0.1 \mathrm{ml}$ of the solutions were injected into a Metrohm $831 \mathrm{KF}$ coulometer filled with Hydranal Coulomat AG reagent. The results were corrected against a freshly opened $100 \mathrm{ppm}$ water standard.

\section{Thermal analysis}

Compounds 1, 2 and 3 were characterized via TGA/DSCthermal analysis. 10-15 $\mathrm{mg}$ each were weighed into an aluminum crucible and heated under $\mathrm{N}_{2}$ atmosphere. TGA curves were recorded in the temperature range of $25-600{ }^{\circ} \mathrm{C}$ using a Netzsch TG 209 F3 system. DSC curves were recorded in the temperature range of $25-450{ }^{\circ} \mathrm{C}$ using a Mettler-Toledo DSC 1 $\mathrm{STAR}^{\mathrm{e}}$ system. A baseline correction was applied.

\section{Conclusions}

The reaction of $\mathrm{NH}_{4}\left(\mathrm{O}_{2} \mathrm{CCF}_{3}\right)$ or $\mathrm{NH}_{4}\left(\mathrm{O}_{2} \mathrm{CC}_{2} \mathrm{~F}_{5}\right)$ with europium metal in liquid ammonia gives yellow $\mathrm{Eu}\left(\mathrm{O}_{2} \mathrm{CCF}_{3}\right)_{2}$ or $\mathrm{Eu}\left(\mathrm{O}_{2} \mathrm{CC}_{2} \mathrm{~F}_{5}\right)_{2}$, respectively. However, to some extent this oxidation process is accompanied by $\mathrm{C}-\mathrm{F}$ bond activation resulting in a recognizable amount of $\mathrm{NH}_{4} \mathrm{~F}$ in the amorphous samples that are extremely sensitive to further oxidation. Bis ( $N, N$-dimethylformamide) complexes of the $\mathrm{Eu}^{\mathrm{II}}$ compounds have been prepared and the crystal structure determination of the trifluoroacetate derivative $\mathbf{1}$ shows the solid of this first lanthanoid(II) perfluorocarboxylate coordination compound to be chain-polymeric with bridging trifluoroacetato and $N, N$-dimethylformamide ligands. Reactions of the $\mathrm{NH}_{4} \mathrm{~F}$-containing samples with the corresponding anhydrous perfluorocarboxylic acid yields ammonium salts of two new dodecakis $\left(\mu_{2}-\right.$ perfluorocarboxylato)octa- $\mu_{3}$-fluorido-octahedro-hexaeuropiate(III) complexes with additional vertex-coordinating acid molecules,
$\left(\mathrm{NH}_{4}\right)_{2}\left[\mathrm{Eu}_{6} \mathrm{~F}_{8}\left(\mathrm{O}_{2} \mathrm{CR}\right)_{12}(\mathrm{RCOOH})_{6}\right]$, with $\mathrm{R}=\mathrm{CF}_{3}(2)$ and $\mathrm{R}=$ $\mathrm{C}_{2} \mathrm{~F}_{5}$ (3). Interestingly, in the case of the pentafluoropropionate an octakis(acid) solvate is obtained. The oxidation state of europium in the unsolvated precursors and in complexes 1, 2 and 3 derived thereof were monitored by ${ }^{151} \mathrm{Eu}$ Mössbauer and photoluminescence spectroscopy. In a subsequent article we will report on the stepwise hydrolysis of the europium(III) complexes presented here, yielding a series of partially and fully vertex-hydrated octahedro-hexanuclear fluoridocarboxylates.

\section{Conflicts of interest}

There are no conflicts to declare.

\section{Acknowledgements}

We would like to thank Jun.-Prof. Dr. M. Suta, Dr. P. Barthen, Dr. G. J. Reiss, Dr. G. Kreiner, E. Hammes, and T. Herrmann for technical support and discussions. Support for this research by the Jürgen Manchot Stiftung (scholarship to F. Morsbach) is gratefully acknowledged. Thanks to the CeMSA@HHU (Center for Molecular and Structural Analytics @ Heinrich Heine University) for recording the NMR-spectroscopic data.

\section{Notes and references}

1 (a) F. Swarts, Acad. R. Belg., 1922, 8, 343-370; (b) R. N. Haszeldine, J. Chem. Soc., 1951, 584-587; (c) R. Hara and G. H. Cady, J. Am. Chem. Soc., 1954, 76, 4285-4287; (d) G. S. Fujioka and G. H. Cady, J. Am. Chem. Soc., 1957, 79, 2451-2454; (e) P. Sartori, J. Fazekas and J. Schnackers, J. Fluorine Chem., 1972, 1, 463-471; $(f)$ C. D. Garner and B. Hughes, Inorg. Chem., 1974, 14, 1722-1724; (g) C. D. Garner and B. Hughes, Inorg. Chem., 1974, 14, 463471; (h) C. D. Garner and B. Hughes, Adv. Inorg. Chem., 1975, 17, 1-47; ( $i$ ) G. J. Reiss, W. Frank and J. Schneider, Main Group Met. Chem., 1995, 18, 287-294; (j) B. F. T. Cooper and C. L. B. Macdonald, New J. Chem., 2010, 34, 1551-1555; (k) A. Llordés, K. Zalamova, S. Ricart, A. Palau, A. Pomar, T. Puig, A. Hardy, M. K. v. Bael and X. Obradors, Chem. Mater., 2010, 22, 1686-1694; (l) K. T. Dissanayake, L. M. Mendoza, P. D. Martin, L. Suescun and F. A. Rabuffetti, Inorg. Chem., 2016, 55, 170-176.

2 (a) R. Dallenbach and P. Tissot, J. Therm. Anal., 1977, 11, 61-69; (b) R. Dallenbach and P. Tissot, J. Therm. Anal., 1981, 20, 409-417; (c) S. Fujihara, M. Tada and T. Kimura, Thin Solid Films, 1997, 304, 252-255; (d) S. Fujihara, S. Ono, Y. Kishiki, M. Tada and T. Kimura, J. Fluorine Chem., 2000, 105, 65-70; (e) D. Czajkowski, I. Simon and W. Frank, Z. Anorg. Allg. Chem., 2019, 645, 402-408.

3 (a) S. Mishra, S. Daniele, G. Ledoux, E. Jeanneau and M.-F. Joubert, Chem. Commun., 2010, 46, 3756-3758; (b) S. Mishra, G. Ledoux, E. Jeanneau, S. Daniele and 
M.-F. Joubert, Dalton Trans., 2012, 41, 1490-1502; (c) S. Mishra and S. Daniele, Chem. Rev., 2015, 115, 83798448.

4 (a) F. A. Cotton and J. G. Norman, J. Coord. Chem., 1971, 1, 161-172; (b) M. Sikirica and D. Gardenic, Acta Crystallogr., Sect. B: Struct. Crystallogr. Cryst. Chem., 1974, 30, 144-146; (c) D. J. Santure, K. W. McLaughlin, J. C. Huffman and A. P. Sattelberger, Inorg. Chem., 1983, 22, 1877-1883; (d) F. A. Cotton, E. V. Dikarev and X. Feng, Inorg. Chim. Acta, 1995, 237, 19-26; (e) F. A. Cotton, E. V. Dikarev and M. A. Petrukhina, Inorg. Chem., 2000, 39, 6072-6079; $(f)$ E. V. Dikarev, A. S. Filatov, R. Clérac and M. A. Petrukhina, Inorg. Chem., 2006, 45, 744-751; $(g)$ B. Li, H. Zhang, L. Huynh, M. Shatruk and E. V. Dikarev, Inorg. Chem., 2007, 46, 9155-9159; (h) E. V. Dikarev, T. G. Gray and B. Li, Angew. Chem., Int. Ed., 2005, 44, 1721-1724.

5 (a) E. V. Dikarev and B. Li, Inorg. Chem., 2004, 43, 34613466; (b) W. Frank, V. Reiland and G. J. Reiss, Angew. Chem., Int. Ed., 1998, 110, 3153-3155; (c) W. Frank, V. Reiland and G. J. Reiss, Angew. Chem., Int. Ed., 1998, 37, 2983-2985.

6 A. F. Holleman, E. Wiberg and N. Wiberg, Anorganische Chemie, Walter de Gruyter, Berlin, $103^{\text {th }}$ edn, 2017, pp. 2288-2311.

7 (a) H. N. McCoy, J. Am. Chem. Soc., 1935, 57, 1756; (b) G. Brauer, Handbuch der Präparativen Anorganischen Chemie, Ferdinand Enke Verlag, Stuttgart, 1st edn, 1975, pp. 1066-1116.

8 F. Ruegenberg, A. García-Fuente, M. Seibald, D. Baumann, S. Peschke, W. Urland, A. Meijerink, H. Huppertz and M. Suta, Adv. Opt. Mater., 2021, 9, 2101643.

9 (a) A. Lossin and G. Meyer, Z. Anorg. Allg. Chem., 1992, 614, 12-16; (b) P. Starynowicz, J. Alloys Compd., 1995, 224, 217219; (c) P. Starynowicz, Polyhedron, 1995, 14, 3573-3577; (d) P. Starynowicz, J. Alloys Compd., 1995, 225, 406-408; (e) P. Starynowicz, J. Alloys Compd., 1998, 268, 47-49; (f) P. Starynowicz, J. Alloys Compd., 1998, 275-277, 815-817.

10 (a) D. G. Karraker, J. Chem. Educ., 1970, 47, 424-430; (b) F. H. Spedding, M. J. Pikal and B. O. Ayers, J. Phys. Chem., 1966, 70, 2440-2449; (c) K. Micskei, D. H. Powell, L. Helm, E. Brücher and A. E. Merbach, Magn. Reson. Chem., 1993, 31, 1011-1020; (d) D. H. Powell and A. E. Merbach, Magn. Reson. Chem., 1994, 32, 739-745.

11 (a) J. W. Bats, R. Kalus and H. Fuess, Acta Crystallogr., Sect. B: Struct. Crystallogr. Cryst. Chem., 1979, 35, 1225-1227; (b) M. C. Favas, D. L. Kepert, B. W. Skelton and A. H. White, Dalton Trans., 1980, 454-458; (c) S. Ganapathy, V. P. Chacko, R. G. Bryant and M. C. Etter, J. Am. Chem. Soc., 1986, 108, 3159-3165; (d) A. Lossin and G. Meyer, Z. Naturforsch., B: J. Chem. Sci., 1992, 47, 1602-1608; (e) J. L. Arias, A. Cabrera, P. Sharma, N. Rosas, J. L. Garcia and S. Hernandez, Inorg. Chim. Acta, 2000, 310, 261-264; (f) S. Gomez-Torres, I. Pantenburg and G. Meyer, Z. Anorg. Allg. Chem., 2006, 632, 1989-1994; $(g)$ L. CañadillasDelgado, O. Fabelo, J. Cano, J. Pasán, F. S. Delgado, F. Lloret, M. Julveb and C. Ruiz-Pérez, CrystEngComm, 2009,
11, 2131-2142; (h) M. Evangelisti, O. Roubeau, E. Palacios, A. Camón, T. N. Hooper, E. K. Brechin and J. J. Alonso, Angew. Chem., Int. Ed., 2011, 50, 6606-6609; (i) G. Lorusso, O. Roubeau and M. Evangelisti, Angew. Chem., Int. Ed., 2016, 55, 3360-3363; (j) A. De, S. S. Pradhan and B. Biswas, J. Indian Chem. Soc., 2017, 94, 1063-1071.

12 (a) S. P. Bone, D. B. Sowerby and R. D. Verma, Dalton Trans., 1978, 1544-1548; (b) K. V. Katti, P. R. Singh and C. L. Barnes, Synth. React. Inorg. Met.-Org. Chem., 1996, 26, 349-355; (c) G. V. Romanenko, N. P. Sokolova and S. V. Larionov, J. Struct. Chem., 1999, 40, 325-329; (d) A. A. Rastorguev, A. A. Remova, G. V. Romanenko, N. P. Sokolova, V. I. Belyi and S. V. Larionov, J. Struct. Chem., 2001, 42, 759-766; (e) V. I. Belyi, A. A. Rastorguev, A. A. Remova, G. V. Romanenko and N. P. Sokolova, J. Struct. Chem., 2002, 43, 587-594; (f) N. P. Sokolova, V. L. Varand, G. V. Romanenko, V. I. Lisoivan, V. P. Fadeeva and L. A. Sheludyakova, Russ. J. Coord. Chem., 2002, 29, 362-368; (g) S. I. Gutnikov, E. V. Karpova, M. A. Zakharov and A. I. Boltalin, Russ. J. Inorg. Chem., 2006, 51, 541-548.

13 A. Rohde and W. Urland, Z. Anorg. Allg. Chem., 2006, 632, 1141-1144.

14 (a) C. G. Pernin and J. A. Ibers, Inorg. Chem., 1997, 36, 3802-3803; (b) C. G. Pernin and J. A. Ibers, J. Cluster Sci., 1999, 10, 71-90.

15 J. Liu, E. A. Meyers and S. G. Shore, Inorg. Chem., 1998, 37, 5410-5411.

16 (a) L. G. Hubert-Pfalzgraf, N. Miele-Pajot, R. Papiernik and J. Vaissermann, Dalton Trans., 1999, 4127-4130; (b) R.-G. Xiong, J.-L. Zuo, Z. Yu, X.-Z. You and W. Chen, Inorg. Chem. Commun., 1999, 2, 490-494; (c) G. Xu, Z.-M. Wang, Z. He, Z. Lu, C.-S. Liao and C.-H. Yan, Inorg. Chem., 2002, 41, 6802-6807; (d) P. W. Roesky, G. CansecoMelchor and A. Zulys, Chem. Commun., 2004, 738-739; (e) V. Baskar and P. W. Roesky, Dalton Trans., 2006, 676679; (f) M. T. Gamer, Y. Lan, P. W. Roesky, A. K. Powell and R. Clérac, Inorg. Chem., 2008, 47, 6581-6583; ( $g$ ) S. Petit, F. Baril-Robert, G. Pilet, C. Reber and D. Luneau, Dalton Trans., 2009, 6809-6815.

17 A. Babai and A.-V. Mudring, Z. Anorg. Allg. Chem., 2006, 632, 1956-1958.

18 (a) A. Rohde and W. Urland, Dalton Trans., 2006, 29742978; (b) D. John and W. Urland, Z. Anorg. Allg. Chem., 2007, 633, 2587-2590.

19 H. N. McCoy, J. Am. Chem. Soc., 1936, 58, 1577-1580.

20 J. K. M. Sanders and D. H. Williams, Nature, 1972, 240, 385-390.

21 B.-K. Ling, J. Li, Y.-Q. Zhai, H.-K. Hsu, Y.-T. Chan, W.-P. Chen, T. Han and Y.-Z. Zheng, Chem. Commun., 2020, 56, 9130-9133.

22 (a) J. C. Warf and W. L. Korst, J. Phys. Chem., 1956, 60, 15901591; (b) J. C. Warf, Angew. Chem., Int. Ed. Engl., 1970, 9, 383.

23 E. O. Fischer and H. Fischer, J. Organomet. Chem., 1965, 3, 181-187.

24 L. L. Pytlewsky and J. K. Howell, Chem. Commun., 1967, 1280. 
25 R. Juza and C. Hadenfeldt, Naturwissenschaften, 1968, 55, 229.

26 J. K. Howell and L. L. Pytlewsky, J. Less-Common Met., 1969, 18, 437-439.

27 I. D. Brown and D. Altermatt, Acta Crystallogr., Sect. B: Struct. Sci., 1985, 41, 244-247.

28 M. Gudenschwager and M. S. Wickleder, CCDC 1045819: Experimental Crystal Structure Determination, 2015.

29 G. Biedermann and G. S. Terjosin, Acta Chem. Scand., 1969, 23, 1896-1902.

30 (a) Y. Cai and J. H. Espenson, Inorg. Chem., 2005, 44, 489495; (b) M. V. d. Voorde, B. Geboes, T. V. Hoogerstraete, K. V. Hecke, T. Cardinaels and K. Binnemans, Dalton Trans., 2019, 48, 14758-14768.

31 H. Bärnighausen, Z. Anorg. Allg. Chem., 1966, 342, 233-239.

32 (a) J. G. Stevens, V. E. Stevens, P. T. Deason, A. H. Muir, H. M. Coogan and R. W. Grant, Mössbauer Effect Data Index, IFI/Plenum Data Company, New York, 1975; (b) S. Golbs, F. M. Schappacher, R. Pöttgen, R. Cardoso-Gil, A. Ormeci, U. Schwarz, W. Schnelle, Y. Grin and M. Schmidt, Z. Anorg. Allg. Chem., 2013, 639, 2139-2148.

33 D. T. Richens, The Chemistry of Aqua Ions: Synthesis, Structure and Reactivity: A Tour Through the Periodic Table of the Elements, John Wiley \& Sons Ltd, Chichester, West Sussex, UK, 1997.

34 M. C. Etter, J. C. MacDonald and J. Bernstein, Acta Crystallogr., Sect. B: Struct. Sci., 1990, 46, 256-262.

35 (a) N. Fuson, M.-L. Josien, E. A. Jones and J. R. Lawson, J. Chem. Phys., 1952, 20, 1627-1634; (b) R. E. Kagarise, J. Chem. Phys., 1957, 27, 519-522.

36 A. Gavezzotti, Acta Crystallogr., Sect. B: Struct. Sci., 2008, 64, 401-403.

37 T. K. Harris and A. S. Mildvan, Proteins: Struct., Funct., Genet., 1999, 35, 275-282.

38 S. Gomez-Torres, Dissertation, Universität zu Köln, Köln, Germany, 2007.

39 K. Binnemans, Coord. Chem. Rev., 2015, 295, 1-45.

40 (a) D. Tu, Y. Liu, H. Zhu, R. Li, L. Liu and X. Chen, Angew. Chem., 2013, 125, 1166-1171; (b) D. Tu, Y. Liu, H. Zhu, R. Li, L. Liu and X. Chen, Angew. Chem., Int. Ed., 2013, 52, 1128-1133.

41 S. H. M. Poort, A. Meyerink and G. Blasse, J. Phys. Chem. Solids, 1997, 58, 1451-1456.

42 V. K. Gramm, D. Smets, I. Grzesiak, T. Block, R. Pöttgen, M. Suta, C. Wickleder, T. Lorenz and U. Ruschewitz, Chem. - Eur. J., 2020, 26, 2726-2734.
43 J. J. Joos, L. Seijo and Z. Barandiarán, J. Phys. Chem. Lett., 2019, 10, 1581-1586.

44 (a) B. Zhang, T. Xiao, C. Liu, Q. Li, Y. Zhu, M. Tang, C. Du and M. Song, Inorg. Chem., 2013, 52, 13332-13340; (b) J.-F. Greisch, M. E. Harding, B. Schäfer, M. Ruben, W. Klopper, M. M. Kappes and D. Schooss, J. Phys. Chem. Lett., 2014, 5, 1727-1731.

$45 X$-Area, STOE \& Cie GmbH, Darmstadt, Germany, 2009.

46 APEX2, v2014.11-0, Bruker AXS Inc., Madison, WI, USA, 2014.

47 (a) G. M. Sheldrick, Acta Crystallogr., Sect. A: Found. Adv., 2015, 71, 3-8; (b) G. M. Sheldrick, Acta Crystallogr., Sect. C: Struct. Chem., 2015, 71, 3-8.

48 K. Brandenburg, DIAMOND, 4.5.1, Crystal Impact GbR, Bonn, Germany, 2018.

49 vario MICRO, 3.1.13, Elementar Analysensysteme $\mathrm{GmbH}$, Langenselbold, Germany, 2015.

50 (a) H. Pink, Z. Anorg. Allg. Chem., 1968, 356, 319-320; (b) M. Sato, S. Kodama and N. Mori, Bunseki Kagaku, 1971, 20, 557-561.

51 H. W. Stone and D. N. Hume, Ind. Eng. Chem., Anal. Ed., 1939, 11, 598-602.

52 R. A. Brand, WinNormos for Igor6, version for Igor6.2 or above: 22.02.2017, Universität Duisburg-Essen, Duisburg, Germany, 2017.

53 CorelDRAW Graphics Suite 2017, 19.0.0.328, Corel Corp., Ottawa, Canada, 2017.

54 SpectrumTM, 10, PerkinElmer Inc., Waltham, MA, USA, 2008.

55 OPUS, 6.5, Bruker Corp., Billerica, MA, USA, 2009.

56 (a) V. V. Chalapathi and K. V. Ramiah, Proc. - Indian Acad. Sci., Sect. A, 1968, 68, 109-122; (b) A. Sharma, S. Kaur, C. G. Mahajan, S. K. Tripathi and G. S. S. Saini, Mol. Phys, 2007, 105, 117-123.

57 (a) M. J. Baillie, D. H. Brown, K. C. Moss and D. W. A. Sharp, J. Chem. Soc., 1968, 3110-3114; (b) J. A. Faniran and K. S. Patel, Spectrochim. Acta, Part A, 1976, 32, 1351-1354.

58 (a) G. A. Crowder, Spectrochim. Acta, Part A, 1971, 28, 16251629; (b) G. A. Crowder, Spectrochim. Acta, Part A, 1971, 27, 1873-1877; (c) G. A. Crowder, J. Fluorine Chem., 1972, 1, 219-225.

59 (a) G. A. Crowder, J. Fluorine Chem., 1972, 1, 385-389;

(b) N. Rontu and V. Vaida, J. Mol. Struct., 2006, 237, 19-26.

60 (a) G. A. Crowder, J. Fluorine Chem., 1972, 2, 217-224;

(b) G. A. Crowder, J. Fluorine Chem., 1973, 3, 133-140. 